\title{
Tipologia textual de Roquette-Pinto no Museu Nacional
}

\author{
Textual typology of Roquette-Pinto at the Museu Nacional
}

hitps://doi.org/10.1590/1982-02672021v29e13

\section{PEDRO LIBANIO RIBEIRO DE CARVALHO²}

https://orcid.org/0000-0002-3061-7736

Universidade de São Paulo / São Paulo, SP, Brasil

RESUMO: Este artigo analisa, por meio do estudo dos tipos textuais usados dentro do gênero discursivo Livro de Tombo e de textos congêneres, a tipologia textual encontrada no Livro de Tombo do Setor de Etnologia e Etnografia do Museu Nacional/UFRJ, quando da reorganização realizada por Edgard Roquette-Pinto, no início do século XX. A perspectiva entre a Coleção Comissão Rondon e outros textos de Roquette-Pinto é o corpus para entender a modificação da antropologia enquanto ciência no Brasil. Ao analisar a catalogação como gênero discursivo examinam-se as mudanças nas descrições dos objetos indígenas em coleções e em textos etnográficos. Com o uso de exemplos, analisam-se as características dos dois discursos simultâneos veiculados pelos textos: o da ciência e o da civilização dos índios. $\bigcirc$ primeiro era descritivo e o segundo, narrativo. Estes discursos se uniam e se separavam de acordo com a organização e função nos textos. Na pesquisa também foi observado que a cultura material dos indígenas não era examinada do ponto de vista das relações sociais nos grupos produtores, mas como estágios de evolução civilizacional conforme as teorias científicas da época.

PALAVRAS-CHAVE: Edgard Roquette-Pinto. Museu Nacional. Comissão Rondon. Documentação museológica. Colecionismo. Etnografia.

\begin{abstract}
1. Este artigo faz parte da pesquisa do projeto de pós-doutoramento "Índios no tombo: livro de tombo como gênero discursivo" (realizado no MAE/USP), no qual estudo descrições dos objetos indígenas das coleções etnográficas nos livros de tombo do Museu Nacional/UFRJ em comparação com outros textos.

2. Pós-doutorando no $\mathrm{Mu}$ seu de Arqueologia e Etnografia da Universidade de São Paulo (MAE/USP), onde dá seguimento à pesquisa realizada no mestrado e no doutorado em Memória Social pela Universidade Federal do Estado do Rio de Janeiro (PPGMS/Unirio). É graduado em Jornalismo pelo Centro Universitário da Cidade, RJ. E-mail: <pedrolibanio@gmail.com>.
\end{abstract}


ABSTRACT: The article analyzes, through the study of the textual types used within the speech genre inventory and similar texts, the textual typology found in the Inventory of the Ethnology and Ethnography Sector of the Museu Nacional / UFRJ, during the reorganization carried out by Edgard Roquette-Pinto, at the beginning of the 20th century. The perspective between the Rondon Commission Collection and other texts by Roquette-Pinto is the corpus for understanding the modification of anthropology as a science in Brazil. When analyzing cataloging as a speech genre, changes in the descriptions of indigenous objects in collections and in ethnographic texts are examined. Using examples, the characteristics of the two simultaneous discourses conveyed by the texts are analyzed: that of science and that of the civilization of the indians. The first was descriptive and the second, narrative. These speeches could be intertwined according to the organization and its function in the texts. In the research it was also observed that the material culture of the indigenous people was not examined from the point of view of social relations of it's producer, rather stages of civilizational evolution according to the scientific theories of that time.

KEYWORDS: Edgard Roquette-Pinto. National Museum. Rondon Comission. Ethnography. Museological documentation. Collection. 
INTRODUÇÃO

Este artigo utiliza a parcela da teoria bakhtiniana que diz respeito aos gêneros discursivos como ferramenta para analisar as coleções formadas por Edgard Roquette-Pinto no Museu Nacional, dentro da esfera de atuação da Comissão de Linhas Telegráficas do Mato Grosso ao Amazonas (Comissão Rondon, 1907-1915). O exame dos Livros de Tombo do Setor de Etnologia e Etnografia (SEE) do Museu Nacional/UFRJ, em diálogo com outros textos, ${ }^{3}$ é o corpus deste texto. A inscrição dos objetos nestes Livros de Registro era uma etapa inicial da narrativa de conhecimento científico, de projeto de nação e também das diretrizes da política indigenista da época. Posteriormente, o produto final era divulgado para a sociedade por meio da imprensa, do museu e de conferências. Minha hipótese é que a etnografia de Roquette-Pinto tinha a catalogação como gênero discursivo por excelência. É na comparação entre os diversos textos que se percebe a expansão dessa catalogação, tanto na quantidade de objetos quanto pelo acúmulo de informações sobre estes e seus produtores. Lilia Schwarcz ${ }^{4}$ salienta que - Museu Nacional está inserido no contexto cientificista da época, em que museus etnográficos vinculavam-se aos "padrões biológicos de investigação e modelos evolucionistas de análise". Essa busca por teorias científicas análogas entre si e formas classificatórias de conhecimento era a condição de produção desse gênero discursivo. Assim, enfatizo o texto e o discurso sobre a escolha do objeto e elaboração de coleções. Por estar impregnado da ciência de sua época, o Tombo não é somente um inventário de objetos, mas um lugar de troca de conhecimento. ${ }^{5}$

Importante ressaltar que essa é uma época marcada pela transição do amadorismo para a profissionalização na antropologia. Roquette-Pinto foi a campo e escreveu o que viu, mas também trabalhou com material coletado, doado e classificado por terceiros. Ao longo do artigo chamo a atenção para os inúmeros atores que também participaram dessa empreitada dentro e fora do museu.

Na primeira parte do artigo, trabalho as definições de gênero discursivo e tipo textual. Segundo o linguista Luiz Antônio Marcuschi, ${ }^{\circ}$ os gêneros são formas relativamente estáveis de comunicação, que regram e são regradas pelos grupos sociais que as utilizam. Já os tipos textuais são características estruturais comuns aos gêneros discursivos. Na catalogação também é possível observar dois discursos que se misturavam dentro e fora do Museu Nacional: o da ciência e o da civilização dos índios.

Na segunda parte do artigo me debruço sobre como o conceito de cultura e cultura material, dentro das teorias científicas ${ }^{7}$ daquele momento, funcionaram como condição de produção deste gênero discursivo.
3. É preciso ressaltar que, até o incêndio de 2 de setembro de 2018, o setor de Etnologia e Etnografia do Museu Nacional, de acordo com Ewbank e Lima Filho (2017, p. 1), detinha um acervo de aproximadamente " 42 mil objetos, dos quais 30 mil se relacionam com grupos indígenas brasileiros". Entendo que a destruição de todo esse acervo deu outra dimensão aos textos que analisaram cada setor da instituição.

4. Schwarcz (1993, p. 92).

5. Ao longo do artigo utilizou-se catálogo também como sinônimo de Livro de Tombo.

6. Marcuschi (2002).

7. A discussão sobre raça era também uma questão socialmente partilhada pelos intelectuais brasileiros da época, no entanto, preferi restringir o escopo do trabalho ao conceito de cultura. 
8. Roquette-Pinto (1912a) e Roquette-Pinto (1917), respectivamente.

9. Trabalho apenas com os Livros de Tombo I, II, III, V e VI. Os livros não são datados, e, embora Veloso Jr. (2019) informe que foram elaborados respectivamente entre os anos de 1906 e 1909, 1910, 1911 e 1912, preferi manter nas referências apenas sua numeração, sem as datas. Uso neste artigo as fotografias das cópias do tombo com as quais trabalhei no momento da tese.

10. Importante ressaltar que não disponho de todas as descrições de objetos citadas em outros textos. Porém, o fato de haver uma grande quantidade de repetições de um mesmo objeto auxiliou minha pesquisa.

11. Artigo de autoria de Roquette-Pinto (1912a) publicado na Revista Brasileira Brasilianische Rundschau.

12. Id. (1917).

13. Marcuschi (2002) salienta que texto, escrito ou falado, é a materialidade do discurso. O texto é concreto. O discurso é veiculado e reproduzido pelo texto.

14. Bakhtin (1997, p. 279), grifo do autor.

15. Costa-Hübes (2014).
E, na terceira parte, analiso como descrições e representações de objetos indicam a transformação da escrita etnográfica. Faço um cotejo, um paralelo, entre - Livro de Tombo, como documentação museológica, e os textos "Notas sobre os índios Nhambiquaras do Brasil-Central" e Rondônia. ${ }^{8}$ Numa perspectiva sincrônica, observo como o desenvolvimento da pesquisa sobre as coleções no período entre 1912 e 1918 se reflete no texto da catalogação que sai do Tombo para esses dois textos mencionados. Dos 23 volumes do Livro de Tombo ${ }^{9}$ existentes no SEE do Museu Nacional e destruídos no incêndio de 2018 , tenho reproduções fotográficas de partes dos onze primeiros volumes. Fotografei o que era mais importante na ocasião e fiz notas de outros documentos. Algumas imagens são páginas inteiras e outras, apenas close-ups de uma ou outra entrada. Ao todo possuo 323 imagens, perfazendo 1.414 itens. ${ }^{10} \mathrm{O}$ artigo "Notas sobre os índios Nhambiquaras do Brasil-Central" 11 é a versão impressa da apresentação feita por Roquette-Pinto no XVII Congresso Internacional de Americanistas, em Londres, 1912. Nele são mencionados 23 objetos Nhambiquaras da Coleção Comissão Rondon. Rondônia ${ }^{12}$ é o relato da viagem à Serra do Norte, realizada em 1912. No livro encontram-se descritos 72 objetos dos Nhambiquara e quarenta objetos dos Pareci, todos anotados como pertencentes à Coleção Comissão Rondon. Dentre todos esses objetos, destacarei aqui flechas, machados, matéria-prima (breu) e trançados Nhambiquara por meio da análise das descrições distintas de itens mais representativos usados em mais de um texto.

\section{AS DIFERENÇAS ENTRE GÊNNERO E TIPO - OS GÊNEROS DO DISCURSO ${ }^{13}$}

Apesar de não ser de definição simples e unificada, o gênero discursivo passa pela função social de um texto determinado por características e argumentos habituais utilizados com frequência por um grupo. Mikhail Bakhtin considera que se há atividade entre seres humanos haverá algum tipo de troca de informação, com o Tombo não seria diferente. Bakhtin subdivide a comunicação em esferas menores que não devem ser consideradas isoladamente. Tais partes devem ser observadas na esfera da utilização da linguagem que "elabora seus tipos relativamente estáveis de enunciados, sendo isso que denominamos gêneros do discurso". ${ }^{14} \mathrm{O}$ enunciado é uma unidade real, como uma frase ou uma parte de um texto, mas não é estanque e é medido pela troca entre os sujeitos dentro desse discurso. Segundo Terezinha Costa-Hübes ${ }^{15}$ os círculos sociais moldam situações de interação em que os gêneros discursivos são usados, o que faz com que determinadas formas de enunciados 
circulem com maior frequência, tornando certos gêneros típicos desses grupos. $\bigcirc$ gênero discursivo atua como suporte dos enunciados. ${ }^{16}$

Nos enunciados encontram-se três elementos principais: conteúdo temático, estilo e construção composicional. ${ }^{17}$ As descrições no Tombo e nos textos conexos possuem todos esses elementos, que seguem uma lógica de catalogação. $\bigcirc$ conteúdo temático é a descrição e/ou representação. $\bigcirc$ conteúdo é o corpo do texto, por exemplo: "Espiga de milho cultivado pelos Índios da Serra do Norte (Nhambiquaras) 2 - 910 - Tenente Francisco de Lemos - Comissão Rondon". ${ }^{18} \bigcirc$ objeto, a espiga de milho neste caso, é a unidade de sentido, a informação. Nos textos de Roquette-Pinto, o estilo pode mudar dadas as características particulares do meio ao qual é veiculado, mas a catalogação procura manter distanciamento científico, sucinto e direto em oposição à comparação e avaliação estéticas. Roquette-Pinto participa da mudança na classificação etnográfica que dá mais ênfase à técnica, à indústria e à matéria-prima do que ao valor estético ou a conceitos como animalidade ou inferioridade. ${ }^{19}$ Por exemplo, o objeto é descrito rapidamente, mas ainda sem um vocabulário controlado: "Tecido de algodão - dos Urupás - ji-Paraná - Col. Dr. Tanajura" ${ }^{20}$ Por fim, a composição é a sequência na qual tudo isso está organizado que, por sua vez, varia de acordo com o texto no qual se insere e com o qual se quer informar. As descrições dos objetos podem ser maiores ou menores por diversos motivos, como em relação às análises anteriores, às dúvidas tiradas ou à relevância do objeto no contexto teórico do autor. Como apresentado no exemplo anterior, falta informação da data da coleta, mas o objeto, a etnia a que pertence, o local da coleta e o coletor estão ali. Fátima Nascimento mostra em sua tese que um diferencial da reorganização do SEE é a ênfase na pesquisa de campo sobre o objeto. As classificações de objetos anteriores a Roquette-Pinto se davam por etnologia de gabinete. Procura-se a representação acompanhada por uma definição específica criada dentro do gabinete. As penas e matérias-primas diversas são analisadas por meio de uma transversalidade entre as áreas do conhecimento, isso se dá para mostrar erudição e tapar uma lacuna informativa das peças sem pesquisa de campo. Como neste exemplo: "Adorno para a cintura (com chocalho) nas danças, feito de frutos de leguminosa enfeitando com uma corda de penas de arara tendo na extremidade uma borla de penas de mutum". ${ }^{21}$ No mais das vezes, o vocabulário controlado era também erudição pura e simples para circulação interna. Como Nascimento informa na descrição do objeto da coleção Stradelli: "6 1 - acangatar (máa-poaró), Uaupés usado nas festas solenes". A representação é em língua nativa e traduzido para o substantivo acangatar, variação do tupi do substantivo canitar, que significa adorno de penas. Tal descrição passa para o Tombo reorganizado como: "4995
16. Mussio (2015, p. 179).

17. Op. cit. (2014)

18. Livro de Tombo I.

19 No entanto, tal valorização estética sobre as coleções do século XIX se manteve por escolhas técnico-políticas do uso de determinadas informações nas instituições e na divulgação ao longo também do século XX. Tal valorização estética se dá na representação de adornos, em especial de plumárias. Nascimento (2009, p. 38, 75-76).

20. Como inúmeras outras, a Coleção Tanajura, bem como a Antônio Pirineus e a Miranda Ribeiro que serão citadas mais adiante, eram parte da Coleção Comissão Rondon.

21. Nascimento (2009, p. 86). 
23. Nascimento (2009, p. 17, 36).

24. Ibid. (p. 33).

25. Ibid. (p. 39-40).
Máa-paoró - diadema - dos índios do rio Uaupés (oferta do Sr. C. E. Stradelli Manaus)". ${ }^{22} \bigcirc$ uso da classificação diadema ainda indica a valorização estética da plumária. Por meio das releituras feitas para a reorganização, o museu também pode ser entendido como um círculo social, um espaço de circulação de informação.

Fátima Nascimento ${ }^{23}$ indica que a quarta seção do Museu Nacional tinha o problema da eterna reorganização do acervo. As diversas coleções tinham catálogos separados, que se iniciam com a publicação de listagem de coleções em relatórios e no guia da Exposição Antropológica, em 1891. Tal separação se dava devido à luta contra os efeitos do tempo nas coleções e à gestão da informação sobre os itens que, segundo Nascimento, eram tanto administrativa quanto para pesquisa e educação. Além disso, organizações e classificações duram um tempo determinado, visto que novos problemas de catalogação surgem conforme são acrescidos novos objetos. Com relação aos registros anteriores a Roquette-Pinto, deve-se salientar que as informações sobre os objetos e seus coletores não eram necessariamente sistematizadas. Havia uma perda de informação que era natural, pelo trabalho administrativo, e até politicamente desejável. Nascimento ${ }^{24}$ entende que tal exclusão de informação é uma forma políitica de apagamento do coletor pelo apagamento ou diluição da sua coleção em outras. Nos catálogos do século XIX, no mais das vezes, o coletor é confundido com aquele que doou a peça. A falta de dados sobre o coletor também cria uma lacuna sobre o contexto da coleta, que se reflete no conhecimento sobre o objeto. $\bigcirc$ coletor e o doador, que poderiam ou não ser a mesma pessoa, eram informações contingentes, os dados que traziam poderiam ou não ser levados em conta na descrição do objeto. Muitas coleções do século XIX eram consideradas casuais, elaboradas por pessoal não especializado, tanto aqui no Brasil quanto na Europa, e eram registros de coleta e de comércio de material etnográfico. Em geral, a coleta era realizada por pessoal administrativo colonial, viajantes, diletantes etc. Grupioni e Nascimento entendem que os objetos pertencentes a essas coleções poderiam não ter uma correlação entre si. Tal amadorismo na coleta cria uma coleção sem base na observação do grupo; assim, o produtor do material tem a função de informante secundário.

A documentação museológica sofria com a falta de informação etnográfica e documental básica. Dessa forma, a erudição se tornava a base das descrições feitas em gabinete. Identificavam-se as penas e os cipós de um determinado ornato, por exemplo, com o intuito de suprir a falta de informação e aproveitar a proximidade com outras áreas do conhecimento. ${ }^{25}$ Isso apresenta de que forma o Tombo era usado para uma comunicação intragrupal.

Trabalhar com Livro de Tombo (ou de Registro, como também é conhecido) significa entender a documentação em múltiplos níveis. O Tombo faz parte do processo 
de documentação museológica. $\bigcirc$ Livro é, ao mesmo tempo, registro administrativo e sistema de informação/recuperação. Traz em si a questão legal da relação do museu com o objeto, isto é, corresponde à ideia cartorial de que só é objeto museológico se estiver inscrito naquele livro. Só sairá do valor de uso cotidiano para adquirir valor simbólico, em esfera de classificação e de representação, se estiver inscrito ali. ${ }^{26}$

Deve-se levar em consideração que a documentação museológica, por ter essa dupla função, transforma as coleções dos museus em "fontes de pesquisa científica ou em instrumentos de transmissão de conhecimento". ${ }^{27}$ Os sistemas de informação podem ter inúmeras formas e graus de complexidade. No caso do Museu Nacional no início do século XX, o Tombo era um inventário com informações sucintas. As relações entre o objeto, a coleção e o museu se davam no Livro de Tombo, que servia tanto para saber se tal objeto foi emprestado ou doado, como para saber a que etnia pertence. De certa forma, os objetos são vistos menos por peculiaridades étnicas e mais por sua materialidade (matéria-prima, tecnologia, função etc.), no entanto, as informações são sempre relativas à sociedade à qual ele pertencia enquanto cultura material. ${ }^{28}$ Muitas informações eram ampliadas ao longo do tempo e inseridas nas descrições. A reorganização de Roquette-Pinto unificou os catálogos de diversas coleções em um livro apenas.

A reorganização do setor começa na folha de rosto do Tombo: "Cada objeto existente nas coleções acha-se provido de um número próprio correspondente a esse catálogo". ${ }^{29}$ Escrito à mão, mais adiante, lê-se: "Este catálogo foi iniciado em 1906". Logo abaixo, a assinatura do responsável, Roquette-Pinto (Figura 1). A forma de classificação dentro do Livro de Tombo se restringia a duas colunas nomeadas, à esquerda, o número de ordem, e à direita, o objeto, contendo o texto que identifica o item. Cada página do livro era dividida em oito linhas, com um item cada. Há que se pensar que os tipos textuais do Livro de Tombo, nesse momento, apresentam "objeto - etnia - local de origem - coleção - data". ${ }^{30}$ Não necessariamente nessa ordem, nem necessariamente com todas essas informações (Figura 2). Em outros textos ou até mesmo no Tombo, as informações podem ser substituídas com o passar do tempo e o acúmulo de conhecimento sobre o objeto ou sobre a etnia. Objetos semelhantes ou até mesmo duplicatas podem ter descrições distintas, dependendo da informação que os acompanha. Tais mudanças revelam a quantidade de pessoas que trabalharam nas coleções e em suas classificações. $\bigcirc$ gênero discursivo é um trabalho coletivo. $\bigcirc$ coletivo também se dá na troca de informações entre distintas áreas do conhecimento.
26. Bottallo (2010, p. 53).

27. Nascimento (2009, p. 33)

28. Ulpiano T. Bezerra de Meneses, 1983 apud Barbuy (2008, p. 33). Bottallo (2010, p. 50).

29. Livro de Tombo I. Os trechos extraídos do Livro de Tombo e demais obras tiveram sua grafia atualizada.

30. Seguindo, mais ou menos, os campos básicos usados até hoje em Livros de Tombo ou de Registro: "nome do objeto, data do objeto, data de entrada na coleção, forma de aquisição, nome do doador (quando for o caso), origem e procedência". Bottallo (2010, p. 57). 


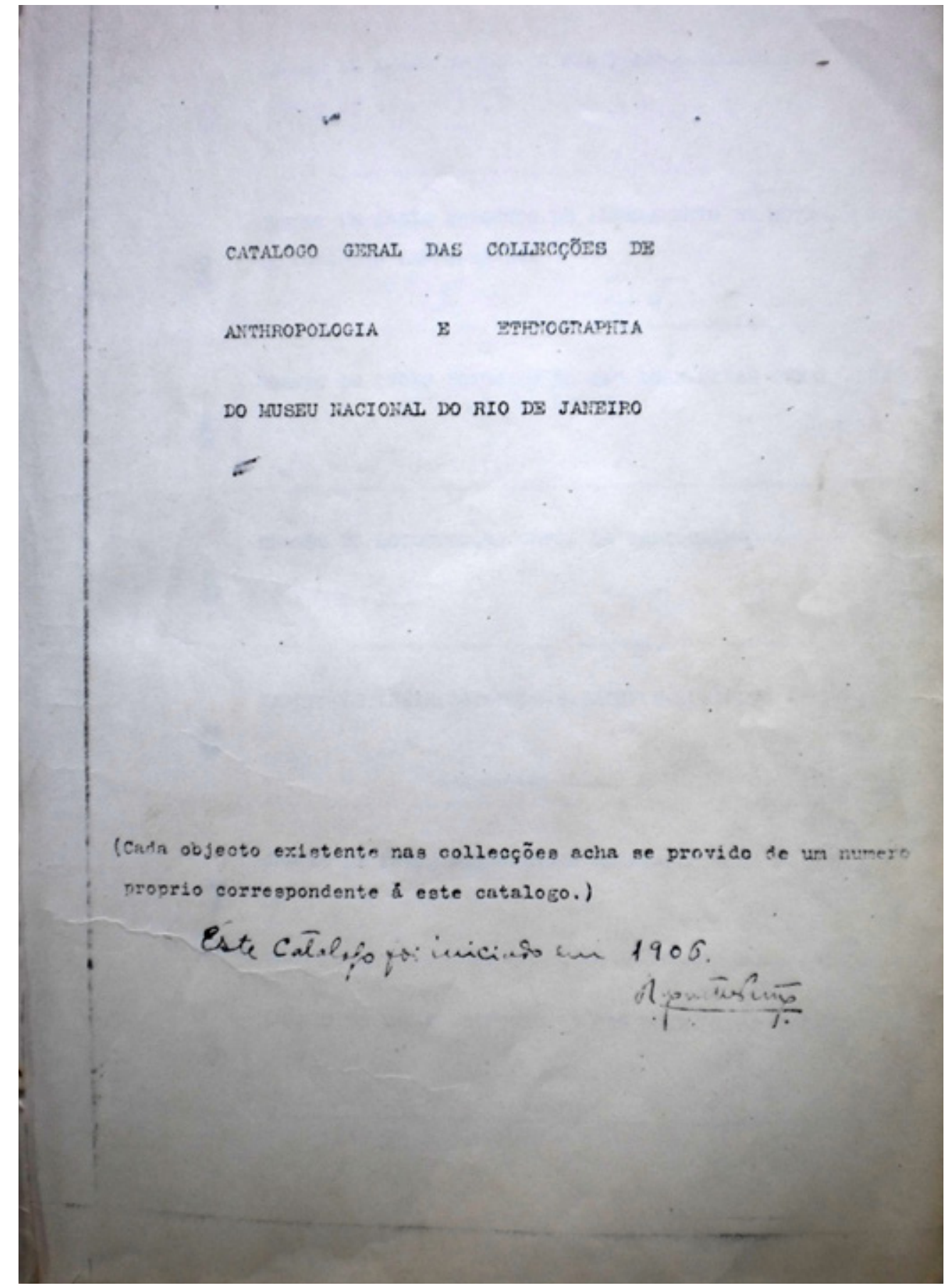

Figura 1 - Folha de rosto do Livro de Tombo I, s/p. Acervo do Museu Nacional/UFRJ. Reprodução do autor 


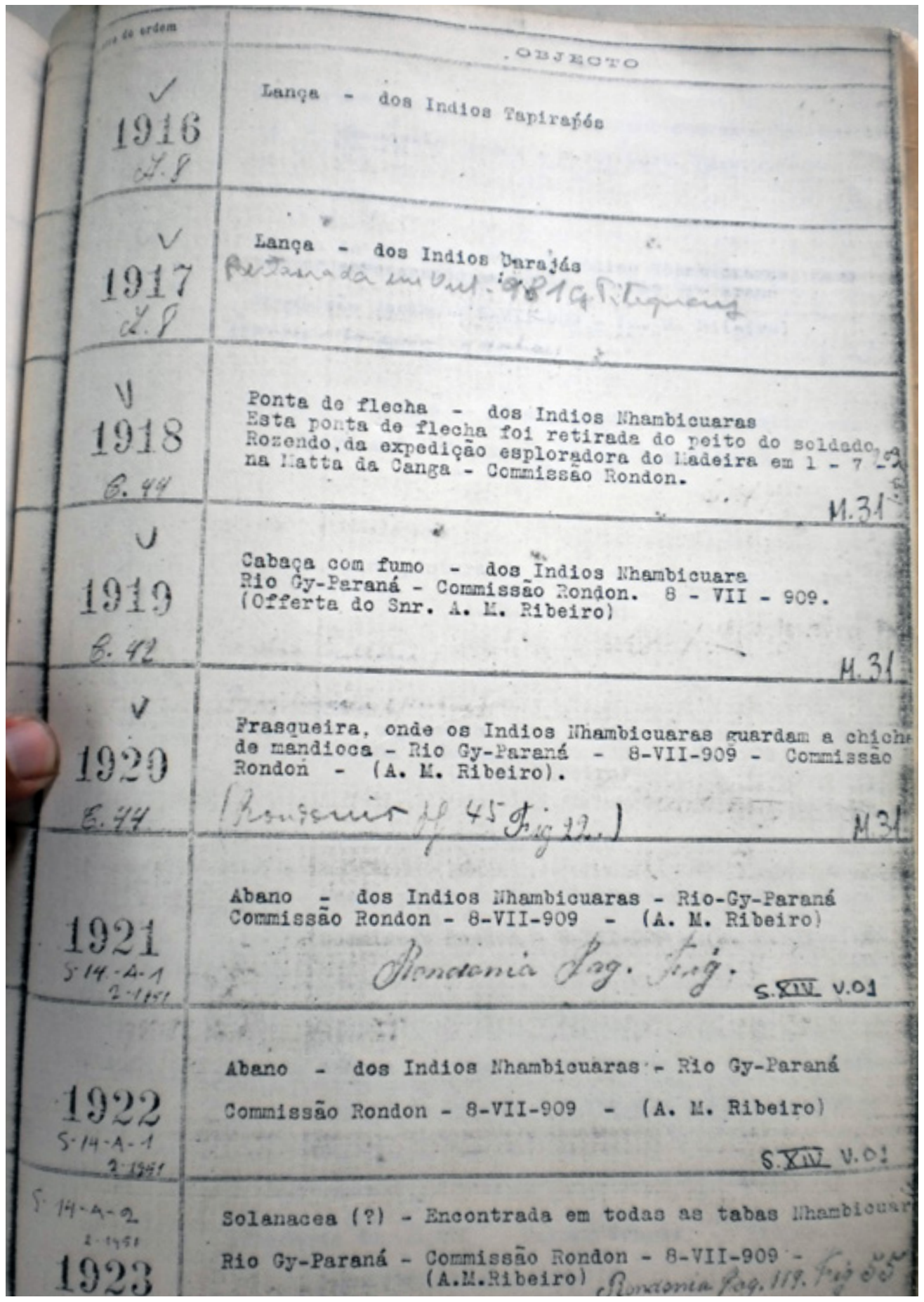

Figura 2 - Página ilustrativa do Livro de Tombo I, s/p. Acervo do Museu Nacional/UFRJ. Reprodução do autor. 
31. Orlandi (2001).

32. O "já-dito" se articula com a memória e remete à filiação dos sentidos usados pelos sujeitos e grupos em determinado contexto. Permite também entender a ligação entre diversos sentidos similares ao longo do tempo. O "já-dito" é o reorganizado. Junto com a memória, é o trabalho de atualização do passado no presente. É a realização de posições anteriores e reatualizadas, visto que nada é cópia pura e simples, mas repetição como reconstrução. Orlandi (2000).

33. Silva (1999, p. 87).

34. Marcuschi (2002).

35. Marcuschi (2002); Silva (1999).

36. Silva (1999).

37. Marcuschi (2002).

38. Grupioni (2008); Lima; Sá (2008).
Tombo e os textos conexos possuem uma estrutura que se articula com a ciência de seu tempo. A catalogação foi uma forma de registrar os estágios de determinadas formas de viver que estavam fadadas à mudança, de acordo com as teorias evolutivas em voga naquele momento. Deve-se ressaltar que tal observação de estágios também cria a objetificação do item. Os registros dos objetos são formas de reorganizar o antigo para the dar um novo sentido. Essa ideia de sentido não é feita automaticamente, ela deriva de algo que se conhece por meio de reelaboração. ${ }^{31} \bigcirc$ "já-dito" 32 no Museu Nacional é a sequência retórica usada por Roquette-Pinto, e o seu sentido é a articulação das teorias científicas usadas para analisar o mundo. As descrições dos objetos devem ser analisadas como pedaços de um sentido maior.

Os tipos textuais e os gêneros discursivos são entrecruzados, mas admitem análises distintas. ${ }^{33}$ Os gêneros discursivos são formados por tipos que constituem os textos e, assim, constituem um discurso. Os tipos textuais são "sequências linguísticas típicas" 34 que têm uma praticidade, um lugar sócio-histórico. São blocos compostos por inúmeras características: a ligação entre vocabulário global e específico (jargão); sintaxe; relações lógicas; tempos verbais etc. ${ }^{35}$ Antonio Marcuschi divide os tipos textuais em cinco categorias: narração, argumentação, dissertação (exposição), descrição e injunção. É importante salientar que, assim como os gêneros, os tipos são móveis e permeados uns pelos outros. ${ }^{36}$ Uma característica dos gêneros é a sua heterogeneidade tipológica. Cada tipo é composto por um conjunto de traços linguísticos predominantes..$^{37} \mathrm{O}$ texto é a materialidade do discurso, o tipo textual, uma ferramenta que auxilia a formação dessa materialidade.

O texto é formado também pelas relações de troca entre os tipos, isto é, pelas sequências de diversos tipos que apresentam o tema central. Por exemplo, o romance é ditado pelo tipo textual narrativo. Mesmo assim, descrições e exposições surgem em função da narração, do estilo do autor, da argumentatividade geral. Os trabalhos de Roquette-Pinto são impregnados pela ciência e pelas dúvidas de sua época. A relativa estabilidade dos tipos textuais reflete o início do profissionalismo da antropologia brasileira e da institucionalização dos museus como ferramenta de análise do país. ${ }^{38} \mathrm{~A}$ reorganização do SEE propicia observar, nos registros dos objetos catalogados, algumas tipologias anteriores e posteriores, evidenciando a mudança na qualidade e na quantidade de informações. Assim, é possível colocar tipologias em perspectiva no Tombo, por exemplo, a modificação das classificações genéricas de "Índios do Brasil" para "Cabixis" ou "Nhambiquaras do Ji-Paraná" diferenciam as etnias. A localização faz parte da geoantropologia, muito difundida no período. Isto é, a ciência do momento se mostrando nas descrições. Neste ponto, o registro do item no Tombo do SEE se encontrava entre a representação (termo) e a 
descrição (palavra). ${ }^{39} \bigcirc$ Tombo, como inventário e sistema de recuperação, é representação, porém, também surge como sequência de palavras em função da descrição do objeto e da narração. Ainda que as descrições/representações dos objetos pareçam informações estanques, podem ser observadas nas articulações dos discursos que se unem e se separam: o da ciência e o da civilização dos índios. ${ }^{40}$

Durante a Revolução Francesa, o estilo artístico neoclássico não representava apenas a forma em si, mas um conjunto de valores sociais da época. ${ }^{41}$ Seguindo a mesma premissa, o cientificismo se mostra como o conjunto de valores desejado para transformar a sociedade brasileira. Assim como o artista faz uso de sua arte para difundir valores, os cientistas devem usar uma forma de explicação de mundo para o mesmo fim. No projeto republicano de nação, os positivistas apresentam a ciência como ferramenta para conhecer e organizar o território. $\bigcirc$ discurso da ciência desenrola-se com tipos textuais descritivos, os objetos são representados pelo termo, descritos por sua função, seu local de origem etc. apresentando estágios evolutivos. Textos que usam tipos descritivos ou expositivos nem sempre seguem uma cronologia, mas uma sequência didaticamente matizada para mostrar graus de importância e operacionalidade. ${ }^{42}$ Não há textos cujos discursos sejam neutros, sem qualquer carga ideológica (na acepção mais ampla do termo). Naquele momento, a etnografia de Roquette-Pinto examinava a cultura material como pano de fundo da mudança de estágios evolutivos. $\bigcirc$ sentido coletivo e das relações sociais eram colocados em segundo plano. Os objetos eram estudados a partir de sua fabricação e dos materiais usados. A atenção à cultura material estava no registro do conhecimento científico sobre os objetos, em sua feitura e em sua composição. Usar a designação científica reconhecida para matérias-primas, fios trançados ou cipós ainda era um resquício da etnografia de gabinete do século XIX. É um "já-dito". No bojo das teorias do final do século XIX e início do século $X X$, o discurso da ciência corresponde ao início da mudança de paradigma na etnografia e no museu. A ciência se configura nos textos do Tombo com base em comparações de estágios evolutivos e em oposição à descrição que se baseia em comparações estéticas. A Coleção Comissão Científica do Império de 1861 , elaborada por Gonçalves Dias, buscou propor relações entre a estética indígena e a grega clássica. Ou como a Coleção Couto de Magalhães, que traz descrições com ênfase no combate, na caça e na inserção do indígena na sociedade. As coleções elaboradas por Roquette-Pinto retiram os objetos de seu valor de uso e os sacralizam enquanto valor simbólico da ciência. Por meio das peças coletadas podia-se mensurar o desenvolvimento do grupo estudado. Como, por exemplo, é apresentado no número de ordem 5874: "Alpercata - feita de embira trançada, imitada dos civilizados, - Índios Urupás do Rio Ji-Paraná - Col. Dr. Tanajura", ${ }^{43}$ a
39. Motta; Oliveira (2006, p. IV).

40. Essa é uma hipótese minha que está sendo melhor elaborada em outro texto.

41. Carvalho (1990, p. 13).

42. Silva (1999, p. 101-102).

43. Livro de Tombo III. 
44. O Museu Nacional... (1916).

45. Miller (2013).

46. Lima (1995).

47. Tacca (2002). data 1912 foi inserida à mão. Parte desse discurso pode ser encontrada em outros gêneros discursivos e em outros suportes, como quando o diretor do Museu Nacional, Bruno Lobo, organizou a divulgação científica e o ensino ao redor de três pontos: coleções "cientificamente organizadas"; aulas "ministradas pelos professores a diversos praticantes"; e conferências. ${ }^{44}$

Já o discurso da civilização dos índios usa mais tipos textuais narrativos, conta eventos e ações que relacionam grupos e objetos dentro de uma história. As sequências de registros de objetos formam uma ideia de anterioridade e de posterioridade, a ordem cronológica de eventos. Em algumas descrições de objetos, essa linearidade dos eventos pode ser colocada em segundo plano para dar visibilidade a um fato principal momentâneo. $\bigcirc$ objetivo dessas narrações é contar a história da interação entre grupos humanos, notadamente entre os agentes do Estado e os índios. A civilização dos índios significa a ideia de ação de um grupo sobre o outro. Não há necessariamente oposição entre eles, mas ação e reação. Neste discurso, muitas vezes a reação é o altruísmo, frequentemente propagandeado pelos militares positivistas. Os objetos descritos e narrados aqui são tanto palco quanto atores dessas ações. É por causa deles e por meio deles que as ações se desenrolam. ${ }^{45}$ Eles são a síntese do contato entre os grupos. Como condição de produção desse discurso, o cientificismo também dá um sentido de evolução por oposição. Tal sentido se encontra na comparação entre os grupos, entre civilizado e primitivo. Esse discurso se baseia numa análise eurocêntrica e evolutiva do mundo. Da mesma forma que o discurso da ciência, o da civilização dos índios também se apoia em outros suportes e passa por outros gêneros. Alguns temas se tornam recorrentes, como apresentado por Souza Lima ${ }^{46}$ era preciso permanecer no spotlight da imprensa para conseguir pleitear os escassos recursos da Primeira República. A ideia de civilização dos índios era muito veiculada nos jornais por meio da palavra "pacificação". Esła designava a aproximação com grupos isolados ou tidos como agressivos. Os primeiros contatos amistosos com os Kaingang, do interior de São Paulo, em 1912, e com os Parintintin, no Amazonas, em 1914, foram notícia nos grandes jornais. A pacificação era sempre narrada de alguma forma. $\bigcirc$ discurso de civilização do índio é a grande divulgação dos trabalhos da Comissão Rondon e da causa da Proteção Fraternal, como ficou conhecida a política indigenista do período. É o que Fernando de Tacca ${ }^{47}$ também apresenta como a imagem do selvagem e do pacificado, a relação entre grupos com a modificação de um deles. Outro tema importante é o da inserção do índio na sociedade circundante. Assim, imagens de aldeias inteiras fazendo ginástica ou de mulheres índias celebrando a bandeira nacional mostram a integração entre os grupos. São as explicações para o grande público de como o Estado e a elite pensante age sobre o território e a 
população. Todo esse discurso é amalgamado na ideia de Proteção Fraternal. Junto à ideia de relação entre grupos há também a do patriotismo e da reorganização do Brasil. Uma articulação entre os discursos da ciência e da civilização dos índios é a ideia de que se devem colocar tais coisas em prática, pois havia a necessidade de aliar teoria e conhecimento empírico. A necessidade de trabalho de campo na etnografia se apresenta. Tal praticidade e abnegação positivista podem ser captados na passagem de Roquette-Pinto durante a conferência "O Brasil e a antropologia", realizada na Biblioteca Nacional (RJ), em 1912, e publicada posteriormente na Revista do Brasil:48 "O que vem comigo é antes temperado de experiência; mas não fará, eu o espero, grave dano ao vosso próprio, perfumado de entusiasmo. Porque ambos, o vosso e o meu, são matizados de esperança".

Deve-se ter em mente que os tipos são divisíveis e intercambiáveis, assim, objetos podem também ser narrados, e a atuação junto à população indígena também pode ser descrita.

\section{OS TEXTOS DE ROQUETTE-PINTO}

\section{O museu, o pensamento de uma época e o conceito de cultura}

Ainda que o Museu Nacional fosse designado como instituição de história natural, ele era também etnográfico. Até a década de 1870, grosso modo, o modelo teórico da etnografia tinha suas bases em uma catalogação iluminista do mundo. $\bigcirc$ humano seria representado em sua diversidade pela quantidade de objetos étnicos e naturais. Com o início da era de ouro dos museus (1 870-1930), a antropologia foi considerada um ramo da medicina/biologia. A pesquisa era física (baseada na antropometria e no estudo comparativo entre corpos) e de gabinete. O subdiretor da seção de antropologia, zoologia e paleontologia do Museu Nacional (1895-1915), João Baptista de Lacerda, atacava a etnografia social por não considerar científica o bastante a descrição social de povos. No próprio Museu Nacional, o primeiro curso da disciplina foi ministrado por Lacerda e focava em anatomia e antropologia física. ${ }^{49}$ Vale salientar que a geração de Roquette-Pinto é entendida como uma geração de transição, marcada não apenas pelo estranhamento em relação ao Brasil, mas também pelo choque com a modificação das ciências ao redor do globo.
48. Roquette-Pinto (1916, p. 322).

49. Schwarcz (1993, p. 93). 
George Stocking Jr. observa que o período áureo da "antropologia museológica" só começou em 1890. Neste momento, os museus europeus, em particular, trabalhavam a cultura nacional com interesse especial pelo folclore. Da mesma forma que se tentou fazer com a Exposição Antropológica de 1882, as exibições se tornaram um departamento dos museus de história natural. Nesse contexto, a universidade se apresentou como berço da antropologia enquanto disciplina. As coleç̃oes etnográficas ainda eram elaboradas por meio das coleções casuais. $\bigcirc$ coletor não trazia boas informações ou estas não eram usadas pelo catalogador, já que as informações eram em geral reelaboradas por eruditos no gabinete.

A maturidade da etnografia vem com a pesquisa de campo servindo como treinamento de pessoal. Fátima Regina Nascimento indica que as anotações corretas sobre coleta de material e pesquisas no local se tornaram padrões de compreensão para as relações entre objeto e sociedade. Portanto, a elaboração de coleções se transformou em paralelo aos modelos teóricos de estudos do homem. Mesmo assim, o evolucionismo ainda era a chave teórica, e a dicotomia entre primitivo e civilizado se mostrava como parâmetro de estudo. $\bigcirc$ início da profissionalização cria a necessidade de deixar de lado métodos intuitivos de coleta e catalogação. No entanto, as coleções casuais ainda persistiam, quando se coleta tudo, não se recolhe informação pormenorizada o bastante sobre os objetos.

A antropologia também participou do turbilhão do século XIX e foi usada como ferramenta em movimentos nacionalistas, de desenvolvimento econômico e, também, imperialista. No contexto mundial, apesar do enfraquecimento do período colonialista, museus se fortalecem pela memória do período áureo do administrador colonial. O museu muda de paradigma para a educação patrimonial no final do século XIX e início do XX. No Brasil Republicano, os museus ganham uma função ordenadora e tradutora. Catalogam objetos ao mesmo tempo que interpretam visões de mundo. Tornaram-se polos de produção intelectual. Tanto o Museu Nacional quanto a Comissão Rondon faziam parte de um projeto maior que visava à integração do país à nova ordem econômica mundial. E o que ficou conhecido como Projeto de Integração Nacional pretendia proteger as fronteiras, criar rotas de escoamento de produção e recolher conhecimento científico sobre o interior. A observação etnográfica estava no escopo do conhecimento do território e da população do interior do Mato Grosso. Por meio da imprensa e da divulgação científica mostravase que o índio poderia ser "transformado" em produtor de riquezas. A antropologia e a etnografia eram as formas de ler e traduzir para o público letrado do litoral a transformação pela qual passava o sertão brasileiro. Nesse sentido, os intelectuais davam um caráter civilizatório ao seu trabalho. Domar o Brasil era a forma pela qual o país alcançaria a modernidade almejada. "Rondônia" era parte da divulgação 
deste projeto. Tal divulgação de conhecimento fazia parte do discurso da ciência que caminhava ao lado do discurso de civilização dos índios.

Para entender a etnografia de Roquette-Pinto é preciso observar os conceitos que perpassam sua geração. Tais textos, enunciados, conceitos ou palavras-chave devem ser compreendidos como "já-ditos" que se articulam na função retórica e na operacionalidade dos discursos. Aqui há também o uso da memória dentro do discurso. Como todos de sua época, Roquette-Pinto faz articulações de sentidos anteriores e que ficam na memória do grupo. São observações sobre posições prévias e reatualizadas dentro do grupo, pois, como apresentado anteriormente, nada é cópia pura e simples, mas repetição e reconstrução. Antes de qualquer coisa, é preciso ter uma visão geral sobre as grandes correntes do pensamento científico da época e como foram reutilizadas no conceito de cultura. Tal como propôs George Stocking Jr., não se trata de inventar conceitos ou definições, mas, sim, interrogar como estes conceitos circularam pelo meio intelectual da época, pois penso que o cientificismo e a modernidade possuíam função retórica nesse tempo e nos seus discursos. A reconstrução histórica do conceito de cultura se dá pela observação de padrões de pensamento que circulavam no meio intelectual da época. ${ }^{50}$

Grande parte desses discursos usam estratégias discursivas que articulam ideias já conhecidas. ${ }^{51}$ Segundo Lúcia Murari, ${ }^{52}$ o positivismo foi suplantando pelas ideias evolucionistas de Herbert Spencer: regidos por leis do progresso orgânico, os grupos andariam num só sentido, indo do organismo mais simples para o mais complexo. Ainda que fosse similar à ideia de Augusto Comte, segundo Spencer as forças não se dissipam, mas se transformam. Em linhas gerais, os pontos de união entre Comte e Spencer eram os "já-ditos" das teorias evolucionistas: fé inabalável no progresso; observação de estágios; evolução das sociedades; e busca de leis gerais que poderiam ser aplicadas a todos os grupos sociais.

Para pensar o conceito de cultura entre o final do século XIX e o início do século XX, é preciso observar dois sentidos específicos: a "cultura humanista" é homeostática, plural e relativista; e a "cultura evolucionista" é progressiva, singular e absolutista. ${ }^{53}$ No entanto, estes sentidos se misturam. Até 1900, a observação sobre cultura era similar na Alemanha, no Reino Unido e nos Estados Unidos, e não possuía as características antropológicas modernas. ${ }^{54} \mathrm{Em}$ especial durante $\mathrm{O}$ período da unificação na Alemanha, o conceito serviu como ferramenta política. A cultura seria representada pelo espírito de união entre os integrantes de uma sociedade "expresso acima de tudo na linguagem e nas artes e nos costumes". ${ }^{55}$ Tal conceito seria uma essência "nacional" (nesse caso particular) que pouco pondera interferências externas, como articulações com outros grupos, empréstimos ou mesmo modismos de uma época. Nessa perspectiva, a cultura se desenvolve 
56. Minicurso a economia... (2019); Ventura (1991).

57. Roquette-Pinto (1916).

58. Id. (1917).

59. Id. (1917); Lobato (1918).

60. Roquette-Pinto (1913, p. 3). de forma homeostática e natural. Diferenciando-se dessa concepção, surge nesse momento a ideia francesa de cultura como civilização. Tal conceito de cultura trabalha com a noção de acúmulo progressivo de características que libertam o homem do animalesco, ou seja, o livram das amarras impostas pelo meio em que vive, por puro reflexo e instinto. A ideia é que há uma espécie de refinamento inerente à capacidade humana de, ao longo do tempo, elaborar, com maior ou menor grau de criatividade, o uso de instrumentos/ferramentas (a ciência) ou da arte, por exemplo. Neste artigo, a cultura é entendida como aproximação à dita civilização ocidental (notadamente, a Europa e parte da América do Norte). Nesse espectro, cultura seria o uso da racionalidade em oposição à força do instinto. Seria o intelecto superando o fetichismo (conceito usado para classificar sociedades tidas como primitivas, se comparadas à racionalidade europeia). ${ }^{56} \mathrm{O}$ conceito de cultura dessa época era singular, ou seja, a cultura seria uma só, distribuída evolutivamente numa escala entre os povos. Assim, o observador se liga ao objeto de estudo, perdendo um pouco do distanciamento científico. Isso coloca o antropólogo no ponto de estudar como aquele grupo ainda não alcançou determinado nível de sofisticação, ou até mesmo, de pensar sobre qual ferramenta poderia ser usada para retirar determinado grupo de determinado nível de cultura. No caso brasileiro, tal ferramenta de administração e "aculturação" seria o exemplo extraído do positivismo ${ }^{57} \mathrm{O}$ cientista coloca o outro como parte de sua concepção de mundo, mesmo que este outro ainda não saiba que a tem ou que chegará a essa concepção. Com a ideia de cultura como evolução, o observador está no topo dessa escala. Superstição, instinto e temperamento eram geralmente associados aos status evolutivos mais baixos. As ideias de selvagem e primitivo eram apresentadas como incapacidade de refinamento ou de poder de abstração. Os "já-ditos" dos estágios sociais evolutivos são apresentados em Rondônia ${ }^{58}$ na comparação entre Nhambiquara e Pareci. No degrau mais baixo estariam os Nhambiquara, apresentados como o homem das cavernas, o primitivo. ${ }^{59}$

Apesar do eco alemão na antropologia e na etnografia brasileiras, RoquettePinto apresenta uma mescla entre cultura como evolução e tradição dentro de uma determinada sociedade. Alguns fatores da pesquisa de campo e das ferramentas conceituais para os estudos dos objetos indicam os caminhos percorridos por este autor. As primeiras observações que fez in loco sobre os Nhambiquara salientaram não terem chefes temporais ou espirituais declarados ou com ostentação; não terem ritos; serem tachados de fetichistas do tipo mais elementar; 60 não falarem português ou terem boas relações com não índios; e possuírem uma cultura material considerada pobre. Neste sentido, a tradição como indicativo do grau de civilização seria mensurável por meio dos poucos objetos usados. Como apresentado pelo próprio 
autor: "Depois do machado de pedra, o utensílio destinado ao preparo do terreno é um simples bastão pontiagudo". "6l Já os Pareci trabalhavam como guarda-fios e operadores de telégrafo, eram ordeiros e civilizáveis. Possuíam mitos e algum poder de abstração. Muitos desses índios falavam pareci e português. A comparação entre as etnias encaixava-se na ideia dos diferentes espectros de cultura/civilização. As relações entre o primitivo e o civilizado foram usadas para manter a Comissão Rondon na mídia e, assim, permitir o prosseguimento do trabalho, dado o já comentado problema orçamentário da Primeira República. ${ }^{62}$

Duas teorias em voga no momento eram aplicadas por Roquette-Pinto em seus textos: difusionismo e invenção independente (determinismo geográfico). Em linhas gerais, o primeiro conceito é a ideia de que há povos, etnias e/ou centros que propagam inovação. Assim, a "cultura", entendida como uso da racionalidade, estaria em um lugar e não ocorreria uma evolução em si, mas por relações interétnicas ao longo do tempo. Como queriam os positivistas, o difusionismo se alinha com as ferramentas do exemplo e da administração para fazer os povos galgarem os estágios da civilização. Já a invenção independente traz a ideia de que grupos distintos entre si criariam conceitos, ideias, mecanismos ou ferramentas em locais diferentes, caso lhes fosse dado um input similar, independentemente de qualquer background cultural, histórico, social ou ambiental. ${ }^{63}$ Vale mencionar a crítica de Franz Boas ${ }^{64}$ às ideias evolucionistas, centrada na ideia de invenção independente e do determinismo geográfico. A força do meio sobre o homem era rebatida com observações sobre as diferenças entre grupos étnicos que viviam próximos ou em condições geográficas similares.

\section{Os diversos autores/atores}

Há diferenças entre o que está no Livro de Tombo, em Rondônia e em "Notas sobre os índios do Brasil central". Segundo Rita Santos, 65 a etnografia de RoquettePinto trabalha com a observação dos usos e costumes. A coleção etnográfica foi usada como narração dessas etnias e como ferramenta para a mensuração de uma evolução cultural. Roquette-Pinto pensava a cultura material como constituída pelos costumes, pois seu estilo catalográfico e fragmentário via nos objetos os vários enfoques a respeito de uma cultura. De certa forma, pensar a cultura material como grau de civilização comporta a ideia de que quanto maior o intelecto na produção, na assimilação e no uso de bens que auxiliem a vida do indivíduo e do grupo, mais civilizado é o grupo. A coleção de objetos faz parte de uma dialética entre as partes
61. Ibid. (p. 3).

62. Lima (1995); Tacca (2002).

63. Stocking Jr. (1982).

64. Boas (2004).

65. Santos (2011, p. 17) 
66. Roquette-Pinto (1917, p. $\mathrm{XV})$.

67. Schwarcz (1993).

68. Santos (2011, p. 90-91).

69. Santos (2011, p. 90)

70. Ibid. (p. 91). e o todo nessa observação científica de país. É por meio da coleção realizada no Museu Nacional que se desenrola a narração de um momento dessa etnia, o instantâneo de uma pureza primitiva que rumava para a civilização ocidental. ${ }^{66}$ Como dito por Lilia Schwarcz, ${ }^{67}$ os museus etnográficos tornaram-se depósitos que usavam a lógica evolutiva para classificar e ordenar a cultura material. Cada etapa era devidamente catalogada e divulgada. No entanto, tal sistema cria a objetificação das etnias estudadas. Neste artigo apresento o problema das diversas coleções e dos diversos coletores que auxiliaram na narração dessas culturas.

Em sua dissertação, Rita Santos especifica que havia três coleções prévias à expedição de Roquette-Pinto à Serra do Norte, em 1912: uma trazida pelo zoólogo Alípio de Miranda Ribeiro em 30 de junho de 1910; uma doada pela Comissão Rondon, que dá entrada no Museu em 23 de janeiro de 1911; e outra doada pelo tenente Antonio Pyrinneus, em 14 de abril de 1912.68

É preciso contextualizar que essas coleções foram amealhadas por certos personagens, mas catalogadas por outros. Como já apresentado, essas coleções se encontram na transição das coleções casuais para as coleções etnográficas, balizadas pela pesquisa de campo, com correta observação e anotação de informações. Ainda que tenham sido coletadas por pessoal ligado diretamente à Comissão Rondon, estes trabalhavam da mesma forma que os agentes coloniais que organizavam coleções casuais. Como já comentado, o artigo "Notas..." é a versão impressa da apresentação de Roquette-Pinto no XVII Congresso Internacional de Americanistas, em Londres, 1912. A apresentação e o artigo foram feitos com base nessas duas primeiras coleções doadas por Miranda Ribeiro, em 1910, e pela Comissão Rondon. Em 1911 . Neste ponto, Roquette-Pinto ainda realiza um trabalho de etnografia de gabinete, catalogando objetos coletados por outros.

Os itens doados por Miranda Ribeiro, em 1910, contavam 49 peças. Os objetos se dividiam em um terço do material dos índios Urupá, o restante era dos Nhambiquara do Ji-Paraná. $\bigcirc$ material destes últimos era composto basicamente de "flechas, arcos, machados, cabaças, cuias, abanos, matérias-primas (breu, plantas)". A doação feita pelo tenente Pyrinneus, em 1912, é a que tem menor quantidade de objetos, nove objetos ("2 pares de pulseiras, 2 colares, 1 par de brincos, 1 enfeite de nariz e 1 jacá pequeno").69

A doação feita em janeiro de 1911 pela Comissão Rondon se diferencia das outras duas em três aspectos principais: ${ }^{70}$

- Foram 306 objetos, sendo dois terços de objetos de combate I"2 10 flechas, 5 machados, 13 arcos e 1 instrumento de fabricação de arcos e flechas"); 
- Teve maior número de coletores: Severiano Godofredo de Albuquerque 11907 a 1910 ); Tenente Paes de Andrade e Miranda Ribeiro (1909); e, "há registros de recolhimentos realizados por Francisco Lemos e Esmeraldo de Albuquerque" (1910);

- Tratava-se de objetos de nove etnias além de Parecis e Nhambiquaras.

Observando o início do profissionalismo da etnografia, o livro Rondônia pode ser entendido como um grande diário de pesquisa de campo. Ali Roquette-Pinto elabora sobre a coleção que organizou, com 2.150 espécimes e cem fotografias, quando da Expedição à Serra do Norte, em 1912. Esta coleção é marcada por uma tipologia que privilegia adornos, instrumentos e objetos naturais /colares, enfeites, pulseiras, flautas, fusos, penachos, pingentes, sementes de milho, cabaças e fragmento de ávore) em detrimento dos objetos de guerra (flechas, arcos e bordunas), ainda que estes também existam. Esta é uma das expedições que dá início às anotações sistemáticas sobre a coleta e que se detém sobre os locais e condições de coleta, ainda que muitos itens ainda estejam marcados somente como "Serra do Norte" ou "Rondônia".

Outro fato digno de nota é que as coleções Comissão Rondon e Roquette-Pinto se misturam ao longo do Tombo. É preciso entender que a Coleção Comissão Rondon é composta de diversos objetos repetidos que serviram de permuta com outras instituições. Ressalte-se que o Museu Nacional servia como avalista científico do trabalho da Comissão Rondon, que tinha a dupla função de ligar centros urbanos pelo fio telegráfico e prover o museu de objetos diversos a serem usados dentro do escopo do projeto de nação. Mesmo com a reorganização iniciada em 1906, a quantidade de coleções acrescidas com doações de origens diversas faz persistir problemas internos de catalogação. ${ }^{71}$ No âmbito da Coleção Comissão Rondon tal problema se torna mais visível devido às inúmeras expedições, diversos locais de coleta e coletores, muitos dos quais militares ou especialistas em outras áreas sem treinamento específico para a coleta de material etnográfico. ${ }^{72}$ Por essa coleta amadora, o objeto etnográfico traz um pouco do coletor, de sua visão de mundo e até da particularidade do momento. Muitas coleções eram formadas por apenas um tipo de objeto, outras continham espécimes mais vistosas, de modo que a cultura material era analisada por diversos lados que, muitas vezes, não davam uma visão ampla. Isso marca o problema da sistematização dos registros no Livro de Tombo. ${ }^{73}$ Além disso, a coleção deve ser analisada como um conjunto de outras coleções. No meu entender, ela foi elaborada por empresas coletoras/doadoras subsidiárias da Comissão Rondon. Essas empresas coletoras abrangem designações tão díspares como expedições, viagens, rios, estações telegráficas, aldeias, cidades, pessoas, além de outras coleções. É igualmente necessário chamar a atenção para o fato de outros profissionais também terem trabalhado nas descrições baseados em suas próprias especialidades. 
74. Ribeiro (1945, p. 13).

75. Veloso Jr. (2019).

76. Ribeiro (1945, p. 14).

77. Veloso Jr. (2019, p. 76).

78. Lima; Sá (2008, p. 61).

79. Lacerda (1911).

80. Lima; Sá (2008, p. 61).

81. Denominação dada entre 1888 até meados do século XX ao Setor de Etnologia e Etnografia do Museu nacional. Roquette-Pinto (1912b, p. 2).
Em conferências realizadas no Museu Nacional, Miranda Ribeiro ${ }^{74}$ afirma que o trabalho de campo etnográfico foi feito por Karl Carnier (1907 a 1908), por Candido Mariano Rondon (1908 a 1912, 1913 e 1915) e por este junto com Roquette-Pinto (1912). No entanto, ao longo dos Livros de Tombo e de outros textos nota-se que há inúmeras discrepâncias entre os nomes de coletores, doadores e coleções. As diferenças mais gritantes surgem no uso do termo "Col. Rondon" e "Com. Rondon" (a diferença entre Coleção e Comissão) e em objetos que não têm coleção especificada, e o coletor/doador é a referência. Isso mostra o Livro de Tombo como gênero discursivo sendo elaborado. Crenivaldo Veloso ${ }^{75}$ aponta que o trabalho de catalogação precisava de pesquisa e que, só em 1912, já haviam sido catalogados mais de 2 mil objetos. A quantidade de trabalho é, possivelmente, um dos fatores que levaram a tais discrepâncias. A catalogação do material ficava a cargo daqueles que coletaram e de experts que não participaram da Comissão, 76 além de preparadores e zeladores, como Eurico Borges dos Reis e Joaquim da Silva Duarte. ${ }^{77}$ Outro ponto que dificultou as distinções entre os objetos pode ser a grande quantidade de doadores de material, que, segundo as conferências de Miranda Ribeiro, não foram os coletores. Alguns destes são relacionados como coleção, como os casos de Carlos F. Hoehne (botânico) e do próprio Miranda Ribeiro (zoólogo). Ao longo dos diversos textos há assimetrias, por exemplo, entre descrições de objetos repetidos e sequências de objetos com descrições diferentes.

\section{Os textos e as ordens}

Em 1911, Roquette-Pinto embarca para Europa, acompanhando João Batista de Lacerda, diretor do Museu Nacional, que foi o delegado brasileiro no Congresso Internacional das Raças realizado na Universidade de Londres. ${ }^{78}$ Lacerda apresentou "Sur les Métis au Brésil", 79 já Roquette-Pinto apresentou "Nota sobre a situação social do indígena no Brasil". 80 Segundo consta, Roquette-Pinto alonga sua temporada na Europa, aprimorando seus conhecimentos em antropologia e biologia. No entanto, como escrito no Relatório $4^{a}$ sessão: ${ }^{81}$

Ao Congresso de Americanistas - (XVIII) - que se reuniu em Londres enviamos uma - Nota - sobre os índios Nhambiquaras, descrevendo os principais documentos etnográficos recebidos do Sr. Coronel Candido Rondon. Sabemos aqui pelo relatório publicado na "Zeitschriff für Ethnologie" de Berlin, Hf, Illu. IV, de 1912, pelo professor Ed. Seler que esta nota despertou grande interesse entre os especialistas reunidos naquela assembleia mundial. 
"Notas sobre os índios Nhambiquaras do Brasil-Central", 82 enviado ao congresso de americanistas, também foi publicado na Revista Brasileira Brasilianische Rundschau. Era um periódico do Conselho do Comércio Brasileiro de Hamburgo que começou a circular em 1912 com edições bilíngues, em duas colunas, alemão e português. O texto versa sobre a coleção do Museu Nacional, com os números de ordem no Livro de Tombo, imagens e descrições dos objetos. $\bigcirc$ material é composto por objetos físicos, glossários, compreensão de subdivisões de etnias, localização geográfica etc. Como já mencionado, este material etnográfico e antropológico foi colhido por Candido Rondon e por Severiano Godofredo de Albuquerque entre os anos de 1910 e 1911, no início dos contatos com os Nhambiquara, e doado por Miranda Ribeiro em junho de 1910 e em janeiro de 1911 (provavelmente, a doação da Comissão Rondon). ${ }^{83}$

Ainda que se tenham inúmeros coletores e doadores, Santos ${ }^{84}$ percebe que "Notas..." e Rondônia trazem análises sobre a cultura material dos Nhambiquara e dos Pareci baseadas em diversas categorias de objetos ("flechas, fusos, machados, diademas, ornatos, cerâmica, cigarros, sementes, instrumento de música"). Deve-se salientar que as coleções são tratadas de formas distintas. A sistematização aqui proposta parte dos objetos e das comparações entre as descrições destes (flechas, machados, breu e trançados Nhambiquara) feitas ao longo desses dois textos e do Livro de Tombo.

"Notas..." apresenta apenas objetos relativos à etnia Nhambiquara que constam do Livro de Tombo I. Como explicitado isso se deve ao fato de terem sido os primeiros objetos coletados e trazidos ao Rio de Janeiro: abano (1) arco (1), bolsa de palha com sementes (1), breu (1), bastões ígneos (1), cerâmica (1), cesta (1), cigarro (1), colares (3), conserva (1), flauta (2), flechas (6), machado (1), plumária (2, apenas descrição). Há pequenas discrepâncias entre os números de ordem e as descrições dos objetos.

$\bigcirc$ artigo "Notas..." é uma amostra do ineditismo tanto dos primeiros contatos quanto da cultura desse povo, e não um trabalho de pesquisa profundo. Como o próprio autor escreve: são as primeiras informações sobre estes indígenas. Trata-se, no meu entender, de um texto preliminar, tanto com relação à etnografia quanto à escrita etnográfica.

Já Rondônia é um trabalho mais profundo, com escrita voltada à narração das culturas. Observa-se isso na crítica social e no exame do fenômeno da aculturação, como vista na época. ${ }^{85}$ Esse livro foi o trabalho de modificação da etnografia, mesmo que mantenha a forma catalográfica de escrita do autor. Os textos têm uma sequência de parágrafos curtos com informações diretas. Alguns temas têm até uma página e meia de descrição; outros, apenas meia página. A 
86. Lima; Santos; Coimbra Jr. (2008, p. 109).

87. Roquette-Pinto (1912a, p. 26).

88. Id. (1912a, p. 35).

89. Id. (1917, p. 8).

90. Id. (1912a, p. 29). etnografia de Roquette-Pinto se baseava na observação da camada de cultura refletida nos objetos. Essa cultura é pensada pelo autor como a camada de conhecimento que se tem do ambiente ao redor, das relações pessoais etc. Essa ideia de cultura é que faz com que todos sejam iguais em potencial, pois saber lidar com seu entorno é uma capacidade que garante a sobrevivência ao homem. A teoria evolucionista de civilização/cultura imanente se apresenta na escrita. A etnografia do autor difere dos estudos feitos até então no Brasil pelo fato de não se fixar em características como animalidade, inferioridade ou comparações estéticas. ${ }^{86} \mathrm{O}$ livro funciona como uma tradução do sertão para o Brasil urbano do litoral, que queria ver o impacto de sua intelectualidade sobre os ditos "bárbaros" do interior. O relato e a coleção organizada mostram a tomada de território e a incorporação da população. Roquette-Pinto faz seu texto passear no discurso da ciência, quando analisa e cataloga objetos; e no da civilização dos índios, quando narra os contatos e ações entre os grupos.

A influência da geoantropologia é percebida nas designações dos locais de moradia, sempre assinalados, e no fato de rios ou bacias hidrográficas funcionarem como referenciais, tanto para posições geográficas como para relações interétnicas.

Iniciando a análise do texto de 1912, "Notas..." traz um preâmbulo com descrições extraídas dos viajantes e de expedições científicas que andaram pelos contrafortes da Serra ou próximos do vale do Jurvena. As poucas informações disponíveis foram dadas por Von den Stein: população ("600"), localização ("confluência do Arinos com o Peixe") relações interétnicas ("viviam em luta com os vizinhos Apiacás [...] Não querem de modo algum relação com os brasileiros)" e técnicas de luta ("atacam as canoas em trânsito para o Pará [... . não resistem abertamente" ${ }^{87}$ Roquette-Pinto aponta que o Dicionário Geográfico do Brasil, de Milliet de Saint-Adolphe, dá a mesma localização, mas os apresenta como "tratáveis e industriosos", fornecedores de alimento e de remadores aos viajantes. Algumas informações foram confirmadas pela Comissão, outras foram tidas como conflitantes. Rondon conseguiu situar melhor os Nhambiquara no vale do Juruena, até os rios Sararé e Galera, afluentes do Guaporé lque outros autores haviam situado erroneamente). Como de costume, o nome é dado por outro, nesse caso, pelo veio dos sertanejos. ${ }^{88} \mathrm{~A}$ etimologia do nome, contudo, só aparece na pesquisa maior: do tupi Nambi - orelha; Kuára - furo. ${ }^{89}$ Os Pareci os designavam: Uáikoákoré e Ouihanierê. Estes últimos de pele mais escura e mais agressivos, situados nas cabeceiras entre o Juruena e o Camararé. ${ }^{90}$

Há uma pequena parte do texto sobre os Pareci. Tal digressão é também descritiva, com informação rápida e sem maiores detalhes, pois já tinham contato com o não índio desde o século XVII. Aponta-se que foram os guias da expedição 
de 1909, mas a responsabilidade por diferenciá-los recai sobre Rondon que, pelo convivio e influência com os Pareci, conseguiu distinguir suas três divisões: Uaimaré, Caxiniti e Cozarini. No entanto, a informação sobre como se dividiam na Chapada dos Pareci só aparece em publicações posteriores: os Caxiniti, na parte oriental; os Uaimaré, na parte central; os Cozarini, na parte ocidental. ${ }^{91}$

É possível observar que tanto em "Notas..." quanto no Livro de Tombo existem as exposições/descrições sobre os itens e seu uso, e as narrações da conquista geográfica e humana. Há que se perceber que, mesmo que os discursos da ciência e da civilização dos índios se entrelacem, podem ser analisados em separado. $\bigcirc$ que se pode examinar aqui é a diferença entre a argumentação de cada discurso. Como apresentado na epígrafe de Rondônia: "E a ciência vai modificando o mundo", 92 podendo a ciência ser aqui compreendida como uma ferramenta para este discurso de modernidade, de civilização dos índios.

Primeiro comparo as descrições de objetos no Livro de Tombo, como documentação museológica, e em "Notas..." que trabalham o discurso da civilização dos índios e que estão no contexto da narração. Nessa etapa inicial, o relato expõe o cunho estatal da ação dos militares junto aos indígenas. discurso desenrola-se em ações e reações entre grupos distintos, dessa forma, os indígenas agem sobre os militares. A vida dos índios é contada na chave da dualidade: brasileiro e índio, civilizado e primitivo. $\bigcirc$ choque entre os grupos é explicitado, mas desmontado ao longo das descrições. A intenção do discurso era mostrar a aproximação, assim qualquer embate é relativizado graças à benevolência do militar e do Estado. O contexto é de dominação de território e de transformação da população, mesmo sendo um discurso montado sobre o signo do altruísmo positivista, da paz e da integração. $\bigcirc$ texto procura contar eventos significativos do contato, mas por ser uma nota não permite que os eventos sejam esmiuçados. Tudo se inicia com o auxílio dos guias Pareci, que liam os sinais deixados em trilhas pelos Nhambiquara. A ação entre grupos começa com uma panorâmica de eventos ocorridos antes da chegada da Comissão; devido a recorrentes ataques de seringueiros a estes índios, os contatos não eram sempre pacíficos. A expedição encontrou aldeias recém-abandonadas, e tudo foi respeitado a fim de angariar a simpatia dos indígenas. Mesmo assim, a expedição foi atacada duas vezes. Relatase uma emboscada dos Nhambiquara na qual uma flecha acerta a alça do rifle de Rondon, e acrescenta-se que a bandoleira (a alça) foi doada ao museu e catalogada sob o número de ordem $2178 .{ }^{93}$ Tal item é importante na história rondoniana, pois foi entregue num lote e destacado dos outros objetos pela história que carrega. A narração também está no registro do Livro de Tombo (Figura 3):
91. Machado (1994).

92. Roquette-Pinto (1917, p. XIV).

93. Esse objeto tem números de ordem diferentes no texto alemão (2177) e no texto em português (2178), sendo este último o certo. Roquette-Pinto (1912a, p. 31). 
94. Livro de Tombo I.

95. Ibid.

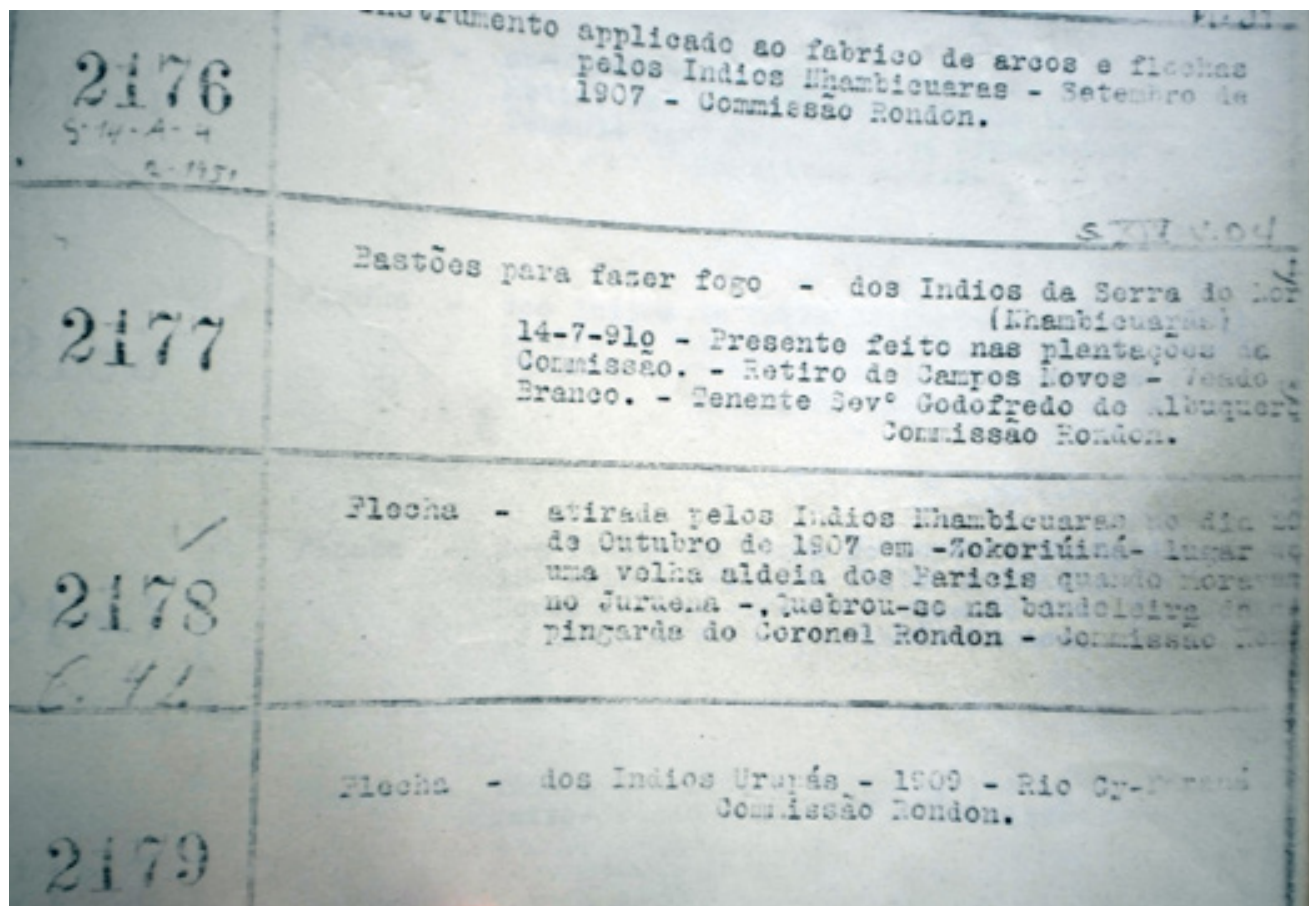

Figura 3 - Detalhe do Livro de Tombo I, s/p. Acervo do Museu Nacional/UFRJ. Reprodução do autor.

Flecha - atirada pelos índios Nhambiquara no dia 20 de outubro de 1907 em - Zokoriúina - lugar de uma velha aldeia dos Parecis quando moravam no Juruena -, Quebrou-se na bandoleira da espingarda do Coronel Rondon - Comissão Rondon. ${ }^{94}$

Um item posterior no tempo, mas anterior na catalogação, não é citado no artigo. Precisa ser citado, contudo, por ter as mesmas características e criar uma perspectiva entre objetos e uma sequência de tipos textuais que constroem a narração do contato no âmbito da documentação museológica. No final, a data está escrita à mão. Sob o número de ordem 1918 descreve-se:

Ponta de Flecha - dos Índios Nhambiquaras

Esta ponta de flecha foi retirada do peito do soldado Rozendo, da Expedição exploradora do Madeira em 1-7-909

na Matta da Canga - Comissão Rondon. ${ }^{95}$

Os itens são eventos e ações bem documentados. No Tombo, a narração está concentrada nas partes da descrição: na data correta, no local bem designado, no fato acontecido, mesmo que a emboscada seja intuída, em quem realiza e em 
quem sofre a ação e na coleção apropriada. As palavras são muito bem escolhidas para que os registros tenham impacto e sejam pontos-chave da narração. Mesmo que tais ações não tenham sido de todo pacíficas, Rondon e Rozendo são os representantes da máquina estatal. Os dois itens estão marcados pela narração do heroísmo, da abnegação e do drama da empreitada. $\bigcirc$ estilo fragmentário de catálogo mostra que a narração reside tanto na descrição do objeto quanto na articulação entre objetos que tratam do discurso da civilização dos índios.

O texto de "Notas..." apresenta que o Retiro do Veado Branco, posto avançado na Serra do Norte, torna-se importante fonte de informações. Essa invernada é chefiada por Severiano Godofredo de Albuquerque, personagem importante desses primeiros contatos e grande doador do Museu. É lá que é feita a maioria dos contatos, em março de 1910, quando os Nhambiquara começaram a roubar feijão e mandioca e a matar animais da invernada. No artigo consta que Severiano segue a linha de Rondon e não revida, fazendo que, com o tempo, os índios se aproximem e comecem a passar alguns dias, o que auxiliou na observação de costumes e na troca de objetos. São apresentados dois vocabulários, um com oito palavras, outro com 31.96 Em "Notas...", RoquettePinto chama a atenção para o fato de que os vocabulários podem confirmar as conjecturas sobre o pertencimento dos Nhambiquara ao tronco linguístico MacroJê. As poucas notas neste primeiro informe versam sobre: dormirem no chão lque teria impacto se confirmadas as suspeitas de pertencimento ao tronco Jêl; os dentes; a cor de caboclo ("aproximada do trigueiro amarelado cor de Caboclo"); as perfurações corporais nas narinas, septo e orelhas; suspeitas sobre o tabaco que fumam; e que plantam milho, cará, batata, mandioca e feijão. ${ }^{97}$ Este era o material que se encontrava no Museu, até a publicação.

As trocas de presentes e a "caça de animais" da fazenda apresentadas anteriormente em "Notas..." também são explicitadas em sequências narrativas no Tombo. Na documentação museológica, mesmo que as entradas dos números de ordem não sigam a cronologia dos eventos, o discurso da civilização dos índios não sofre qualquer distúrbio. Não há um corte na narrativa, como é possível observar nas sequências de flechas, todas com a mesma descrição, entre os números de ordem 2109 e 2112 (Figura 4):
96. Roquette-Pinto (1912a, p. 31-32).

97. Ibid. (1912a, p. 34-35). 


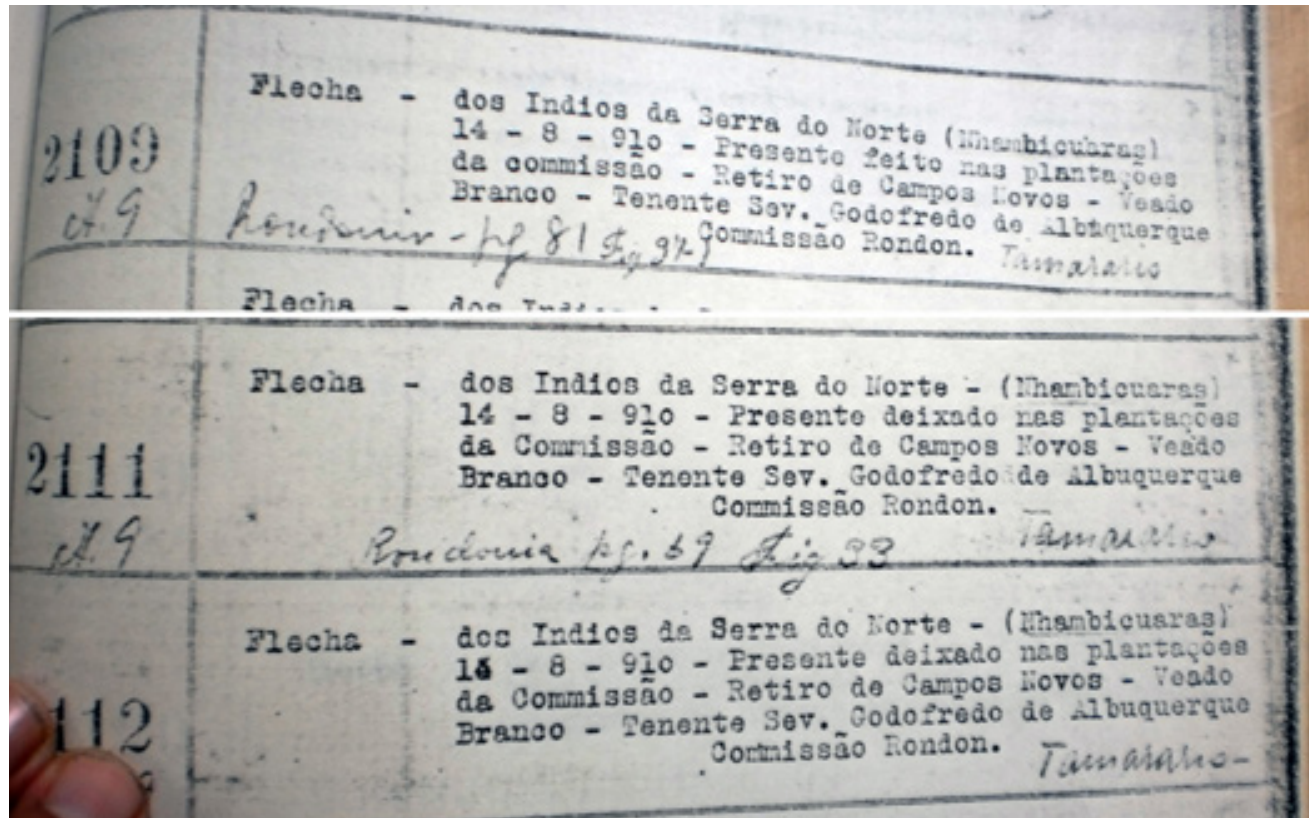

Figura 4 - Detalhe do Livro de Tombo I, s/p. Acervo do Museu Nacional/UFRJ. Reprodução do autor.

Flecha - dos Índios da Serra do Norte - (Nhambiquara)

14 - 8 - 910 - presente deixado nas plantações da Comissão - Retiro do Veado Branco

- Tenente Sev. Godofredo de Albuquerque

Comissão Rondon ${ }^{98}$

No Tombo, os números de ordem 2146 e 2147 contam outro evento relatado no artigo (Figura 5):

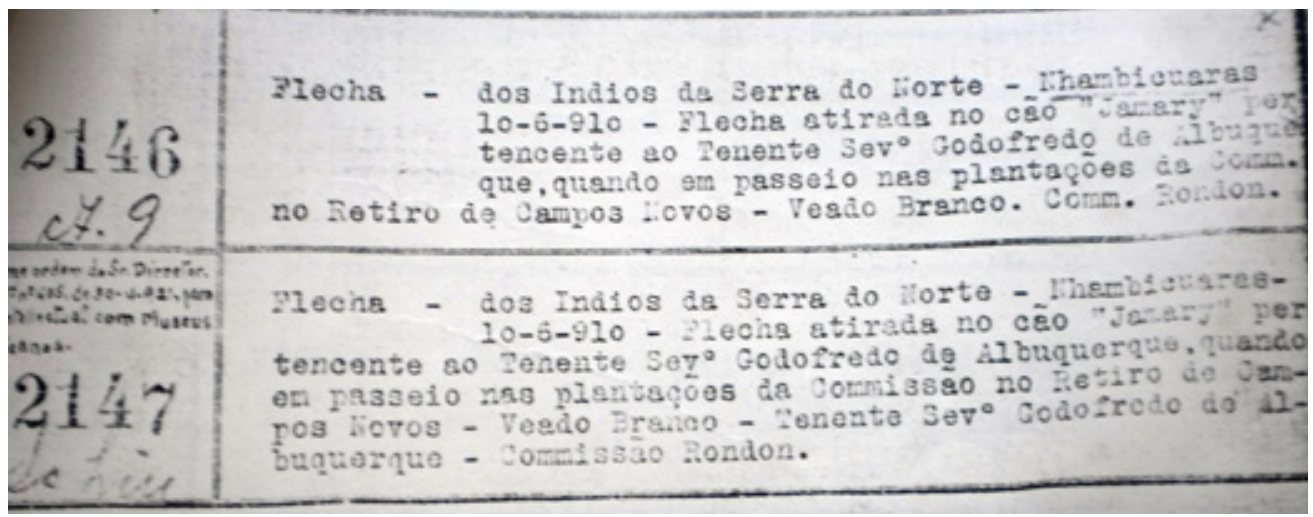

Figura 5 - Detalhe do Livro de Tombo I, s/p. Acervo do Museu Nacional/UFRJ. Reprodução do autor. 
Flecha - dos Indios da Serra do Norte - Nhambiquara

10-6-910 - Flecha atirada no cão "Jamary" per-

tencente ao tenente $\mathrm{Sev}^{\circ}$ Godofredo de Albuquerque

que, quando em passeio nas plantações da Com.

no retiro de Campos Novos - Veado Branco. Com. Rondon. 99

Nos dois textos a união entre os discursos se dá pela maior aproximação entre a Comissão e os índios. As trocas de objetos entre os grupos marcam essa aproximação e se tornam uma marca da etnografia do momento. Assim, os objetos começam a ser representados também por seus nomes étnicos. Os textos ganham detalhes sobre a fabricação e o uso de diversos itens, como veremos mais adiante. Deve-se também salientar que em todos os textos estudados não há uma "paz selada entre os expedicionários e os índios", mas uma sequência de eventos que leva a entender que o contato seguiu seu curso e obteve êxito, até a aproximação efetiva com os índios. Não há apenas uma documentação do contato interétnico entre índio e não índio, mas há um uso estatal dessa narrativa do contato. Uma primeira etapa do discurso da civilização dos índios foi levada a cabo.

\section{Similaridades e diferenças sobre espécimes e coleções}

Há pontos em que se pode notar a união e a distância entre os discursos da ciência e da civilização dos índios em "Notas...". Algumas descrições merecem destaque quando em cotejo com outros textos, porque fogem do estilo de uma apresentação inicial. As descrições de arcos e flechas trazem maiores detalhes sobre a fabricação, pois atravessam também o discurso da ciência. Assim, a coleção mostra que os arcos são "muito grandes, muito fortes, de madeira vermelha e muito bem alisados", e que há variações de tamanho entre $1,80 \mathrm{~m}$ e $2,38 \mathrm{~m}$. A corda é de tucum com $2 \mathrm{~mm}$ de diâmetro, é preciso uma força de $60 \mathrm{k}$ para retesála. Em geral, as flechas têm $50 \mathrm{~cm}$ e são de cinco tipos, diferenciadas pela forma das pontas que também vão designar o uso (Figura 6): 100 


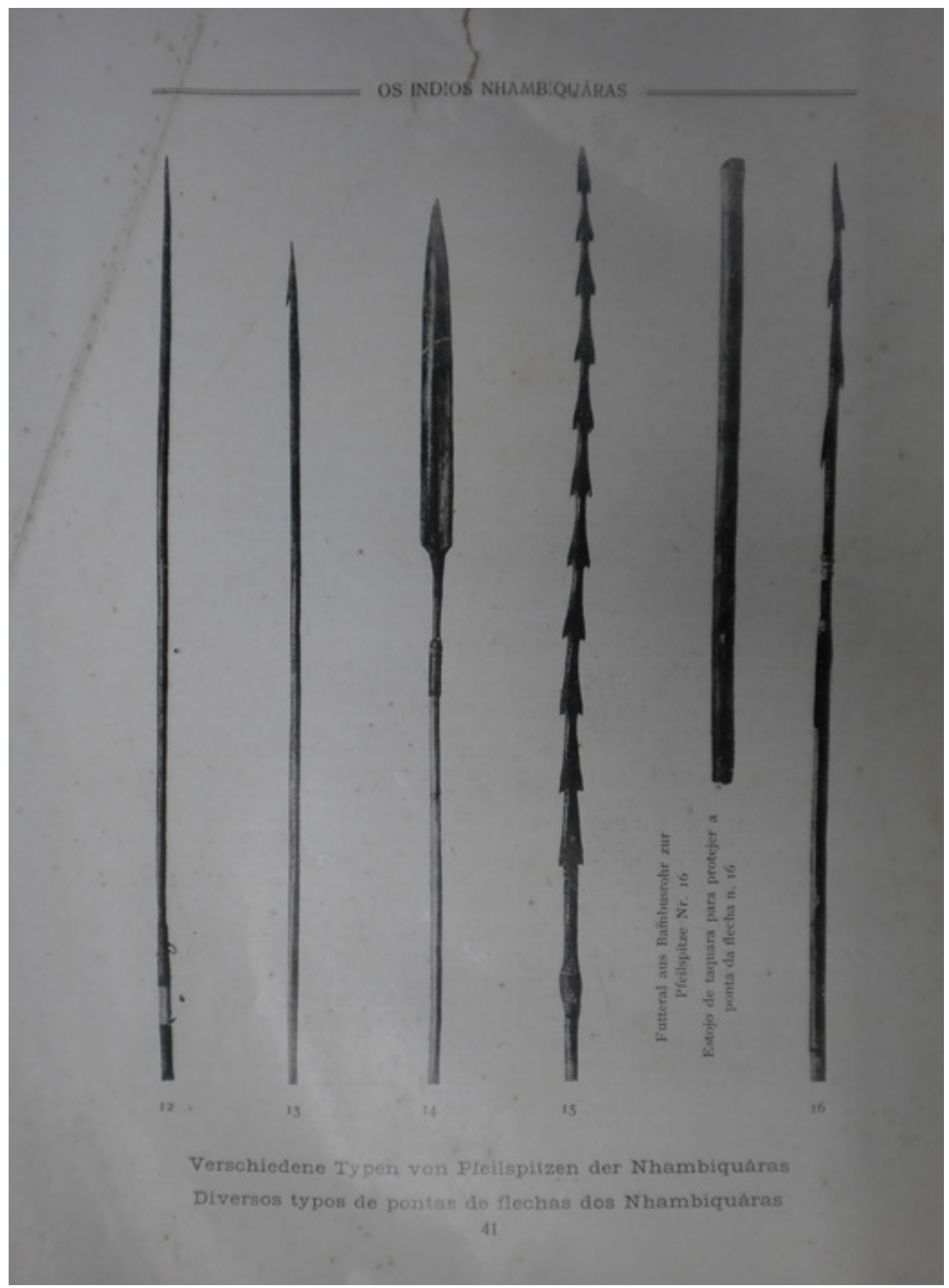

Figura 6 - Descrição das flechas no texto do artigo, da esquerda para a direita: "ponta de madeira vermelha $\left(n^{\circ}\right.$ de ordem 2007); forma de arpão (tem acúleo fixado que lhe dá esta forma, $n^{\circ}$ de ordem 2144); ponta de taquara em forma de punhal aproximadamente $25 \mathrm{~cm}\left(\mathrm{n}^{\circ}\right.$ de ordem 2103); ponta achatada com 11 pares de farpas ( $n^{\circ}$ de ordem 1955); com farpas e um tubo de taquara como bainha (n de ordem 2206)". Fonte: Roquette-Pinto (1912a, p. 41). Acervo da Academia Brasileira de Letras. Reprodução do autor. 
Com os avanços dos estudos sobre a cultura material dessa etnia, RoquettePinto separa as flechas de acordo com o emprego (como caça, pesca e guerra). Mas ficou sabido que os índios usavam as flechas conforme a necessidade e a disponibilidade, ou seja, "quando se faz preciso, os índios empregam, indiferentemente, qualquer, tipo". ${ }^{101}$

A partir daqui farei uma aproximação maior entre os textos com relação às flechas. Ao longo do Tombo muitos artefatos têm nomes étnicos revelados e/ou seus usos e materiais explicitados, ainda que de forma sucinta, conforme o tipo textual relacionado ao discurso em que insere. Algumas flechas deixadas de presente na invernada ganham destaque e são marcadas em Rondônia por seus nomes étnicos e suas especificidades quanto ao uso. Um ponto que chama a atenção é a múltipla identificação, como variações de grafia ou a distância entre as imagens e a descrição no corpo do texto. Na figura 37,102 é o mesmo objeto de número de ordem 2109 (que aparece na Figura 4) identificado com seu nome étnico Aiê-uinçú e descrito como flecha dos índios da Serra do Norte, mais de cem páginas depois, ${ }^{103}$ no entanto, surge a descrição, sem imagem e sem número, da flecha Aiêuinçú (sic), de "ponta lisa, munida de uma farpa na extremidade". Deve ser feita, então, uma comparação da figura com a descrição para se certificar de que se trata da mesma peça (Figura 7). Similarmente, a flecha de número de ordem 2111 (identificada também na Figura 4), Anieeçú, na figura $33^{104}$ aparece como Aniêçú e traz o mesmo número de ordem ao final: "ponta de madeira vermelha, cilíndrica, lisa, com que caçam macacos (2111)" (Figura 7a). ${ }^{105}$

No paralelo entre Tombo, "Notas..." e Rondônia, observa-se que os tipos textuais ganham dimensão com a ação expressa pelos verbos. Ou seja, conforme se aprofundam os estudos sobre a cultura material, aumentam as informações dos tipos textuais. Os textos saem da fórmula apresentada no Tombo lobjeto, etnia, local, coleção, coletor/doador e data), e o tipo ganha outros contornos. Como já mencionado, por ser eminentemente descritivo, o discurso da ciência ganha mais elementos na descrição. $\bigcirc$ cotejo entre os textos mostra a transformação não apenas do discurso, mas da própria ciência.

No texto no número de ordem 2103 (Figura 8): "Flecha - tomada a Índios Cabixis perto da cidade de Mato-Grosso - 1907 - Comissão Rondon", 106 temos: o objeto, a ação, quem a sofre, onde ela se desenrola e a data. Por ser também descrita em "Notas..." confirma-se que se trata de flecha da etnia Nhambiquara. ${ }^{107}$ A descrição científica foi usada como ferramenta neste discurso de civilização dos índios, de ação entre grupos. Cabixi era a designação dada pelos habitantes de Vila Bela da Santíssima Trindade (hoje cidade do Mato Grosso) ao subgrupo Nhambiquara Uáikoákoré. O termo é da língua Pareci e tem sentido pejorativo,
101. Roquette-Pinto (1917, p. 184).

102. Ibid. (p. 81).

103. Ibid. (p. 184)

104. Ibid. (p 69)

105. Ibid. (p 184).

106. Livro de Tombo I. O verbo tomar tinha uso corrente, como no objeto de número de ordem 5785, a "cesta - tomada dos bugres do rio carvão - núcleo Uraisanga? Ano de 1887- Daniel Pedro Muller Chag." Livro de Tombo III.

107. Roquette-Pinto (1912a, p. 42). Descrita como "ponta de taquara em forma de punhal aproximadamente $25 \mathrm{~cm}$ ". 
108. Machado (1994); Roquette-Pinto (1917). pois é usado para referir-se aos índios tidos como menos civilizados. Os Pareci, dos subgrupos Caxiniti e Uaimaré, davam o mesmo nome ao subgrupo Cozarini. A região da cidade do Mato Grosso era uma área de contato entre Pareci Cozarini e Nhambiquara Uáikoákoré. ${ }^{108}$ Rondon foi o primeiro a diferenciar Pareci de Nhambiquara e iniciar uma relação pacífica entre todos os grupos.

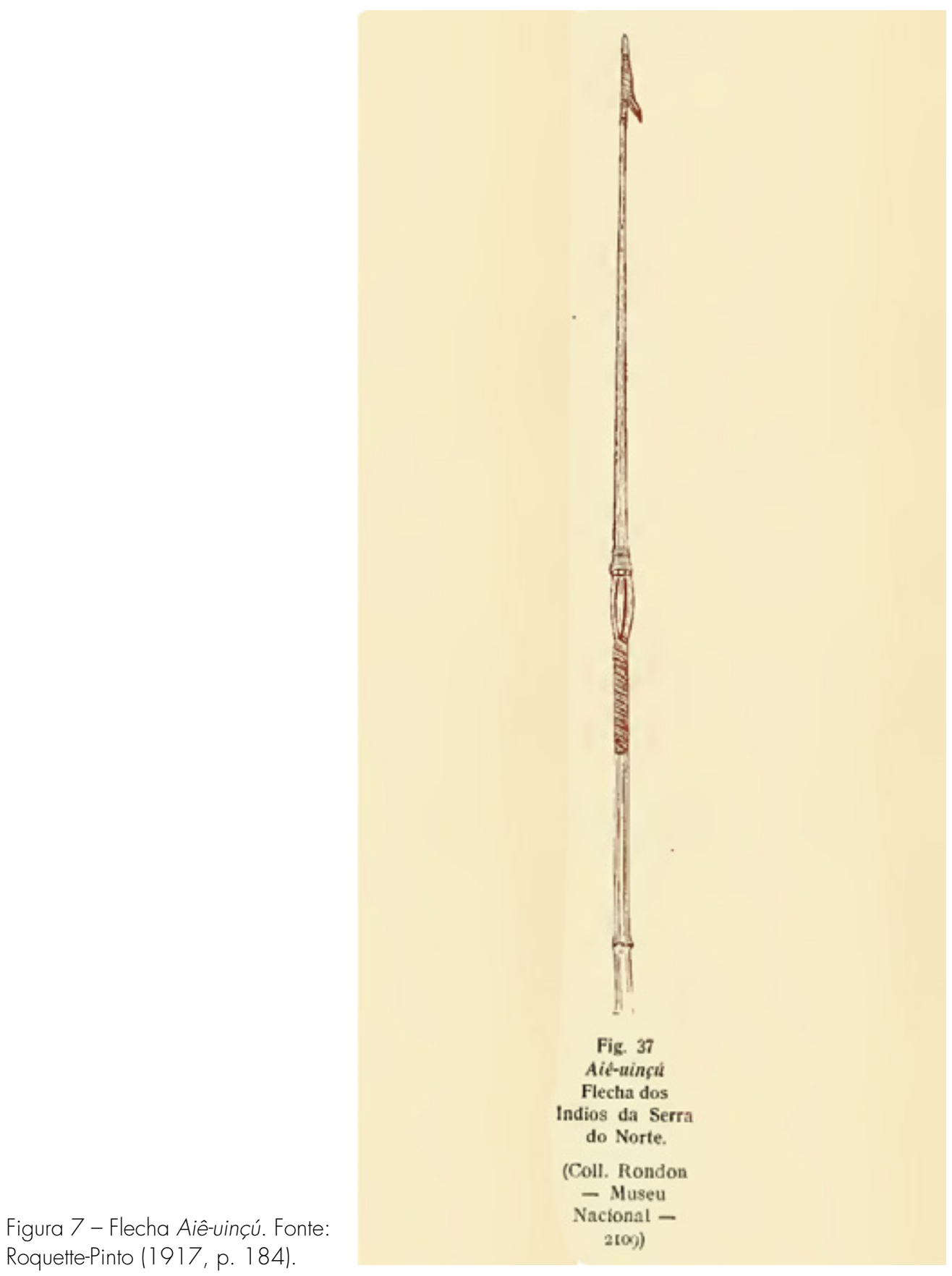




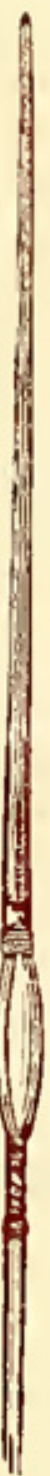

Fig. 33

- Anieegú -

Flecha

de ponta lisa $e$ cylindrica -

Indios da Serra do Norte.

(Coll. Rondon

$$
\text { - Museu }
$$

Nacional - 2(11)

Figura 7a - Flecha Anieeçú. Fonte: Roquette-Pinto (1917, p. 69). 
109. Livro de Tombo I.

110. Roquette-Pinto (1912a, p. 41$)$.

111. Roquette-Pinto (1917, p. 184).

112. Ibid. (p. 185).

Figura 9 - Detalhe do Livro de Tombo I, s/p. Acervo do Museu Nacional/UFRJ. Reprodução do autor.

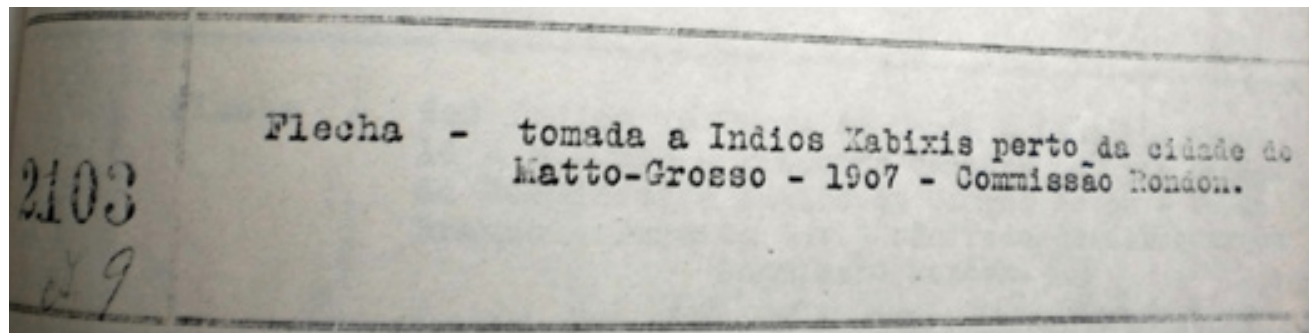

Figura 8 - Detalhe do Livro de Tombo I, s/p. Acervo do Museu Nacional/UFRJ. Reprodução do autor.

Ainda que os primeiros contatos pacíficos com os Nhambiquara indicassem que as teorias evolucionistas do momento se confirmariam e que estes caminhariam inexoravelmente para a civilização ocidental, alguns conceitos são usados no intuito de amarrar discursos para que soem unívocos. $\bigcirc$ uso das teorias da invenção independente e do difusionismo surgem ao longo dos textos como adendos de informação, trabalhando como função fática para a ligação entre os discursos. Ou seja, a ideia de união entre os discursos de ciência e de civilização dos índios segue uma linha lógica na qual o confronto entre sinais de difusionismo e relações interétnicas atesta a tese da cultura como grau de civilização.

Para apresentar a mudança das descrições dentro do discurso da ciência, uso como exemplo o número de ordem 1955 (Figura 9). O texto no Livro de Tombo é sintético e segue a estrutura simples: "Flecha - dos Índios Nhambiquaras - Rio Ji-Paraná 1910 - Comissão Rondon - (A. M. Ribeiro)". 109 É necessário cotejar os textos para entender a circulação da informação sobre este item. Em "Notas..." ela tem "ponta achatada" e "1 1 pares de farpas". 110 Além destas características, Rondônia apresenta informações que modificam radicalmente o objeto: "não é próprio dos Nhambiquaras. Representa troféu guerreiro (1955)". ${ }^{111}$ É curioso que a descrição não detalhe as relações interétnicas nem como tal objeto foi parar ali. Mesmo que muitas perguntas não sejam respondidas e representem uma parcela importante do estudo da cultura material da época, Rondônia corrobora a ideia de que havia contato com outras etnias além dos Pareci. Em sua excursão à Serra do Norte, Roquette-Pinto atesta que as bordunas Nhambiquara eram pedaços de pau e galhos encontrados no momento da refrega. A coleção conta também com itens estrambóticos: "Uma clava trabalhada e polida, revestida de tecido de palha do tipo Carajá (1 1933)" e "um pente de madeira (12046)"112 (Figura 10).

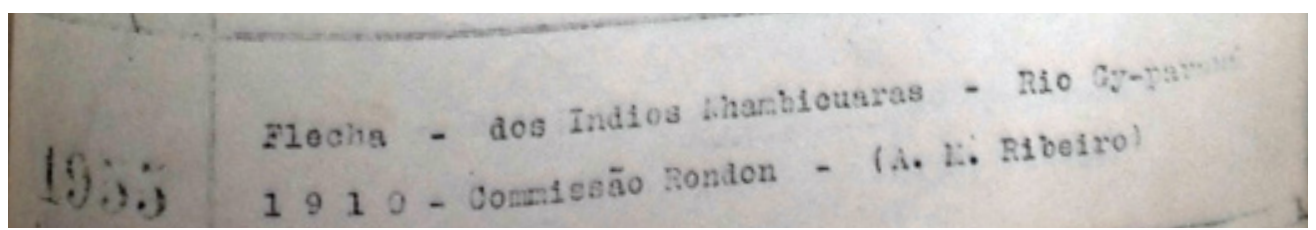




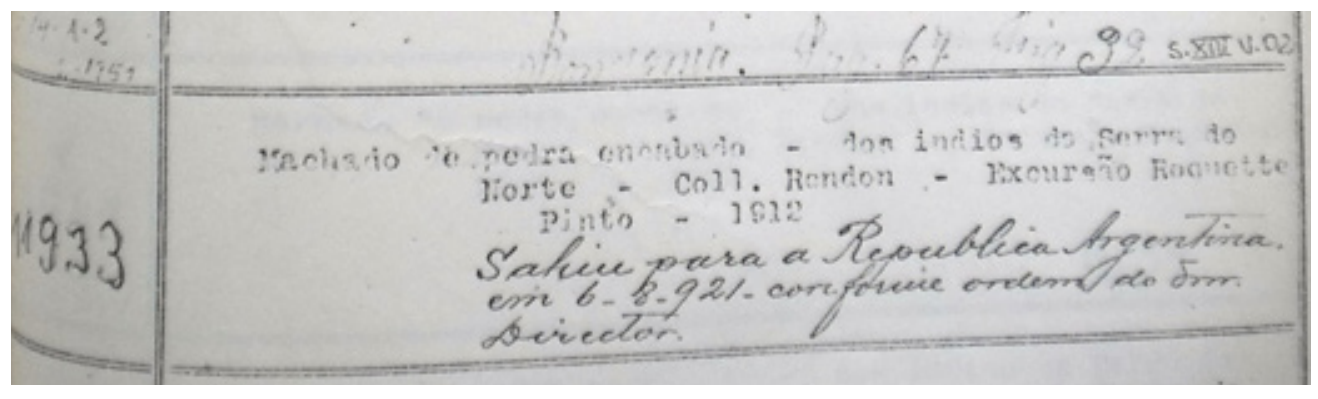

Figura 10 - No Livro de Tombo V, o número de ordem 11933 não é borduna de índios da Serra do Norte ou clava tipo Carajá, mas machado de pedra encabado. Acervo do Museu Nacional/ UFRJ. Reprodução do autor.

A invenção independente é perceptível em "Notas..." na flecha de número de ordem 2206. Roquette-Pinto informa ser a mais curiosa, pois, além das farpas fixadas por fios de tucum e breu, possui um tubo de taquara como bainha. Os Pareci atestavam que se usava veneno nessas flechas, mas o ineditismo estava no revestimento. ${ }^{113} \bigcirc$ texto de Rondônia traz seu nome étnico no número de ordem 1 1487: "Arukirikatçú é tipo perfeitamente original". ${ }^{114}$ A descrição acrescenta detalhes sobre a fixação das farpas com breu e o cipó Imbé, em vez de tucum, mas se adensa com o esclarecimento sobre como o veneno era aplicado e o uso da flecha: "É revestida de um induto negro que os índios supõem tóxico; por isso protegem-lhe a ponta com bainha, feita de colmo de taquara (1 1487). É arma de guerra". 15 No Tombo, o texto do número de ordem 11487 sai um pouco da estrutura usual, e o objeto é apresentado por seu nome étnico "Arikirikatçú" (com uma pequena diferença de grafia). Já a representação para o museu salienta outra característica "flecha com ponta protegida". O restante do registro mostra as imbricações entre empresa coletora e coleção: "dos Nhambiquara - Col. Rondon - Excursão Roquette Pinto - Mato Grosso. 1912 - Serra do Norte" (Figura 1 1, 1 la, 11 b). ${ }^{116}$ Ainda que tenham números de ordem diferentes, os objetos são repetições de um mesmo objeto. A quantidade de duplicatas no Tombo joga luz sobre a modificação da etnologia, na medida em que tais objetos eram usadas como moeda de troca com instituições internacionais. Mais uma vez é importante ressaltar o papel da etnografia no projeto republicano de nação, o Brasil participou ativamente da troca de informação e material etnográfico. O Museu Nacional se tornou um grande hub etnográfico internacional. É importante pensar que a catalogação e designações são elaboradas conforme a quantidade de informação disponível sobre os objetos. $\bigcirc$ primeiro estudo de 1912 apresenta a hipótese de que a mesma flecha usaria dois tipos de breu diferentes. A bainha serviria para proteger o breu com veneno, que poderia derreter quando exposto ao sol. Já o breu que prende as penas à base da flecha poderia ficar exposto ao sol. A análise do professor Álvaro Ozorio de Almeida,
113. Roquette-Pinto (1912a, p. 42).

114. Id. (1917, p. 184).

115. Ibid. (p. 184)

116. Livro de Tombo V. 
117. Roquette-Pinto (1912a, p. 42).

118. Vellard (1939). da Faculdade de Medicina (RJ), não encontrou veneno nas flechas, e as pessoas por elas feridas não tiveram sinais de intoxicação. ${ }^{117} \bigcirc$ livro Rondônia informa que a bainha existe para proteger o usuário de um veneno inócuo. Jean Vellard, que participou da expedição de Claude Lévi-Strauss de 1938, confirma que os Nhambiquara faziam um curare simples e eficaz, similar a outros da região amazônica, mas com durabilidade de poucas semanas. Até que a flecha chegasse ao laboratório, no Rio de Janeiro, o veneno já havia perdido o efeito. Estamos diante de um momento de transição na etnografia: de um estudo de gabinete para a força da observação e coleta dos objetos em campo. Em seu artigo, Vellard atesta que, com a coleta dos ingredientes e a atenção ao modo de cozimento do veneno, era possível reproduzir o curare em ambiente controlado e melhor analisá-lo. ${ }^{18}$ Isso indica os novos contornos da etnografia.

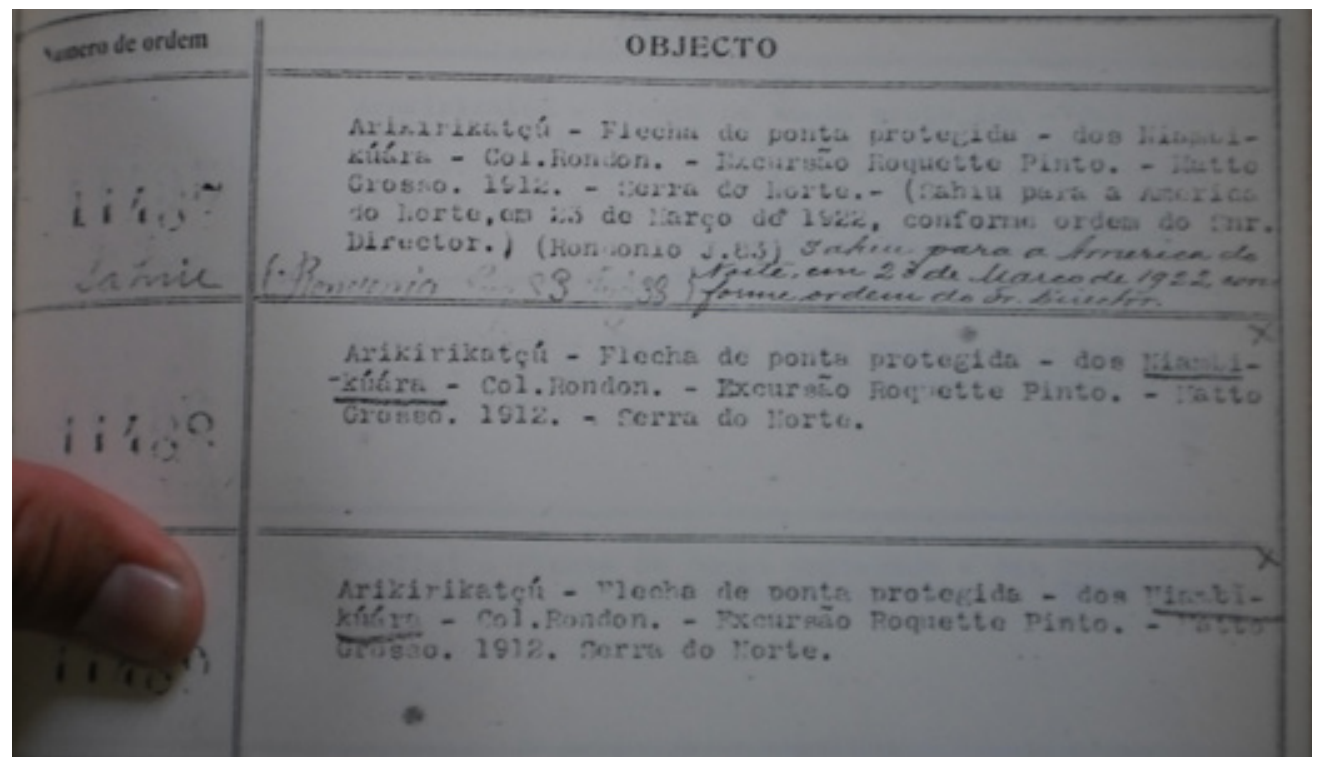

Figura 11 - Detalhe do Livro de Tombo V, s/p. Acervo do Museu Nacional/UFRJ. Reprodução do autor.

A partir deste ponto dou destaque aos machados. Durante a pesquisa no Livro de Tombo do Museu Nacional me deparei com itens avulsos e com sequências: de flechas, de adornos, de ligas tibiais, de machados etc. Entre as sequências e os avulsos encontrei os machados de número 1945 e 1946, e outra sequência que termina em 2213 e 2214 . As descrições apresentam pequenas discrepâncias, no entanto, a análise sobre o uso e as relações entre objetos mostra que são repetições, cópias uns dos outros. As informações sobre os machados de pedra seguem o padrão do tipo textual descritivo do Tombo, especificam a etnia Nhambiquara e a localização geográfica rio Zococoreza (número 1945) e sudoeste do rio Juruena (número 1946), coletados com um mês de diferença, entre setembro e outubro de 1909, por "A. M. 
Ribeiro" (Figura 12). Os últimos números das sequências, 2213 e 2214, não especificam a etnia, mas uma caracterização os diferencia dos objetos anteriores: "Machado encabado - dos Índios da Serra do Norte. 14-7-9 10 - Retiro de Campos Novos - Veado Branco - Sev Godofredo de Albuquerque. Comissão Rondon". 119

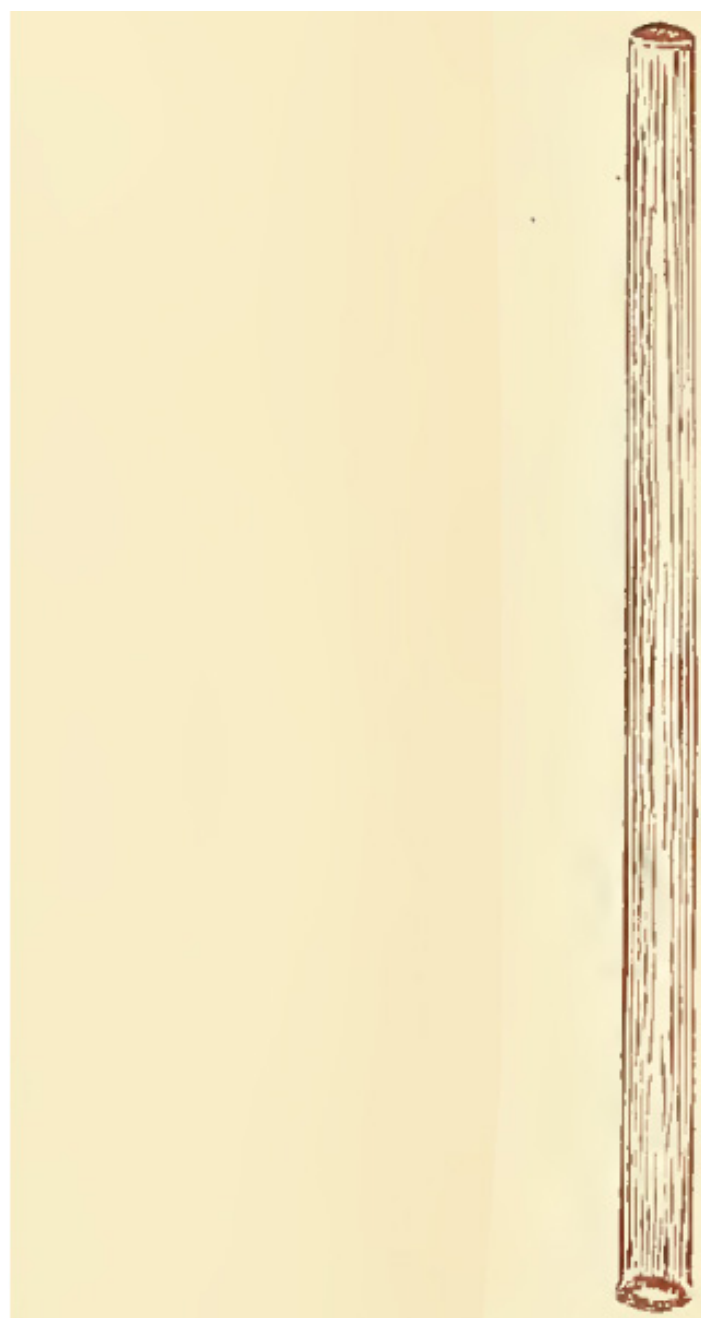

119. Livro de Tombo I.

\section{Fig. 38 - Bainha para proteger a ponta das flechas arukirikatçú dos Indios da Serra do Norte. \\ (Coll. Rondon \\ - Museu \\ Nacional - 11 437 )}

Figura 1 la - Bainha da flecha Arukirikatçú. Fonte: Roquette-Pinto (1917, p. 82). 
Figura $11 b$ - Flecha Arukirikatçú. Fonte: Roquette-Pinto (1917, p. 89).
Fig. 41 -

A rukirikatcú Flecha de ponta embainhada

Indios da

Serra do Norte.

(Coll. Rondon

Mluseu

Nacional -

'11407) 


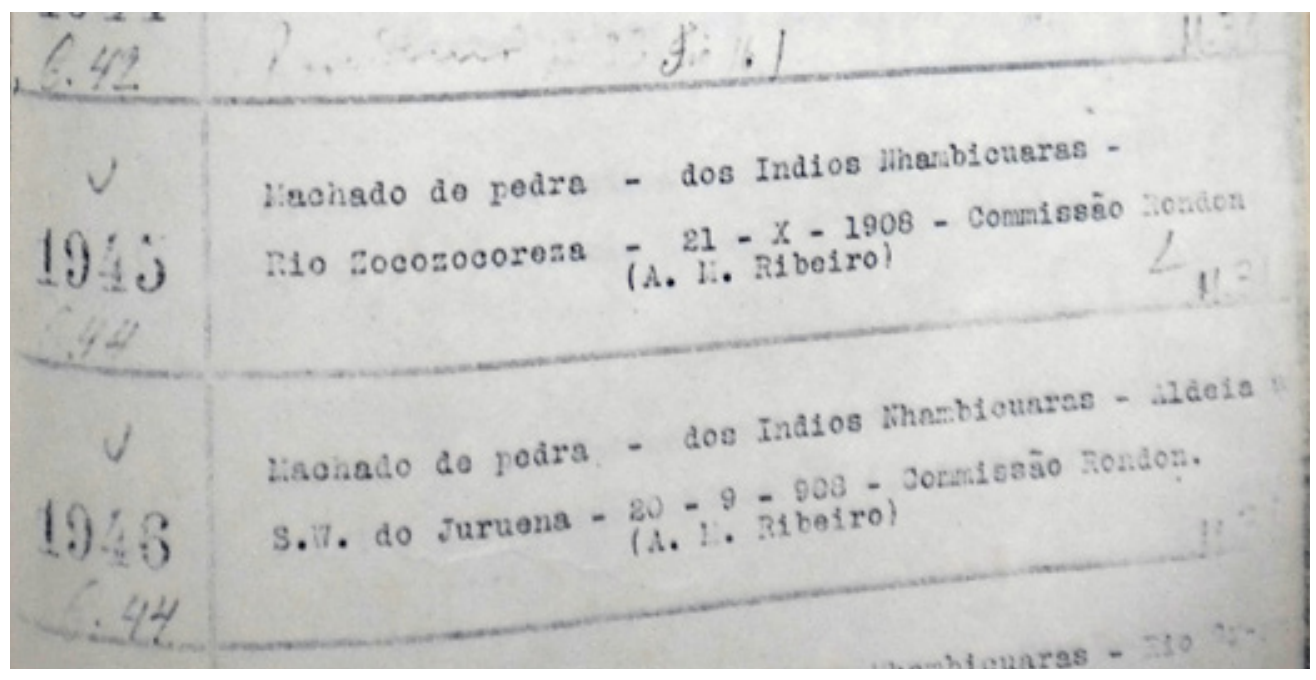

120. Roquette-Pinto (1917, p. 113).

121. Id. (1912a, 1913, 1917) 122. Id. (1913, p. 3, 1917, p. 169-171)

Figura 12 - Detalhe do Livro de Tombo I, s/p. Acervo do Museu Nacional/UFRJ. Reprodução do autor.

Mesmo que na figura 52 de Rondônia seja definido apenas como "Machado de pedra dos índios da Serra do Norte", 120 o objeto com o número de ordem 2208 é o tipo modelar (este item também aparece em "Notas...") (Figura 13). $O$ tipo textual descritivo usado em outros textos segue o parâmetro das informações fragmentárias que dão a visão geral: feito de diabásio, cuneiforme, com peso médio de dois quilos, preso ao cabo de madeira por cordéis feitos de um caule flexível e breu. ${ }^{121}$ Os números de ordem 1945, 1946 e 2213 são representações deste modelo. São itens repetidos. Ainda que as descrições do Tombo apresentem discrepâncias, paralelos com outros textos mostram que, mesmo sendo feitos de forma tão simples, são sólidos e com cabos resistentes. ${ }^{122}$

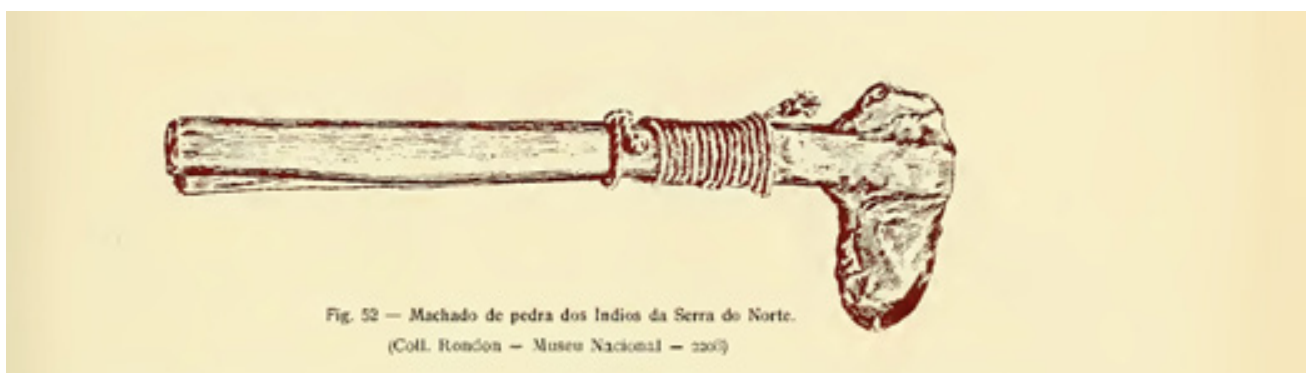

Figura 13 - Machado de pedra dos Índios da Serra do Norte. Fonte: Roquette-Pinto (1917, p. 82).

O texto de Roquette-Pinto menciona as modificações do discurso da ciência, apontando para pequenas correlações entre a cultura material e a sociedade dos Nhambiquara. O sistema catalográfico de Roquette-Pinto dá aos textos características monadistas, pois cada objeto pode ser interpretado como pedaços 
123. Roquette-Pinto (1913, p. 3).

124. Id. (1917, p. 184); Livro de Tombo VI.

125. Id. (1912a, p. 40).

126. Id. (1917, p. 111); Viveiros (1958, p. 235).

127. Ibid. (p. 137).

128. Livro de Tombo II. de informação isolados que representam o todo. Quando analisados em conjunto, o todo se mostra similar às suas partes mínimas. Os tipos textuais descritivos permitem a análise do objeto, de sua constituição e de seu uso tanto prático quando social. Roquette-Pinto relaciona o machado ao ato de cortar uma árvore, como fato em si e como rito de passagem. Afirma que a pedra derruba a madeira mais rapidamente do que se imagina. Mesmo que as partes contenham o todo, algumas pequenas partes não são tão repetidas como outras. Encontrei apenas uma descrição rápida sobre o corte coletivo de árvores de $2 \mathrm{~m}$ de perímetro, que chamou a atenção do antropólogo. ${ }^{123}$ No cotejo entre Rondônia e o Tombo, o número de ordem 13333 é pedaço de madeira derrubada com o tipo de machado coletado por Roquette-Pinto quando da sua expedição de 1912 no ribeirão Amarante (Figura 14). ${ }^{124} \bigcirc$ rito de passagem da derrubada de árvore é comentado ainda em "Notas...": quem consegue derrubar determinadas árvores ganha "como prêmio uma bela pena de arara ou mutum - (Crax globulosa, Spix) - destinada ao nariz". Enquanto generaliza que outras etnias conferem distinções "ao mérito guerreiro", 125 informa que os Nhambiquara distinguem o trabalho industrial.

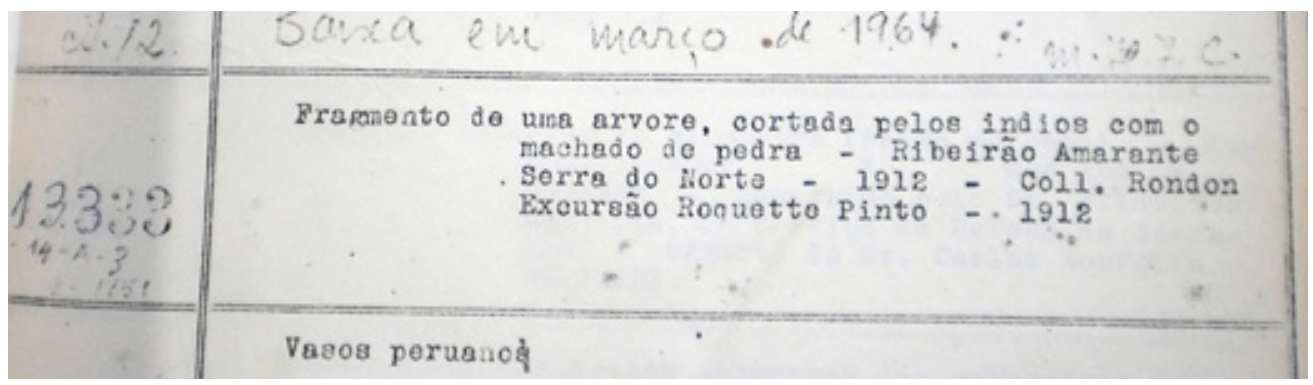

Figura 14 - Detalhe do Livro de Tombo IV, s/p. Acervo do Museu Nacional/UFRJ. Reprodução do autor.

Os presentes levados ao sertão tinham a dupla função de amenizar os primeiros contatos e servir como barganha por material etnográfico. Dentre os muitos brindes, o ferro era o mais cobiçado pelos indígenas. Na história rondoniana, os Nhambiquara dariam tudo o que poderiam por um machado de ferro. Este metal tinha o mais alto valor de troca, e o presenteado se sentia muito honrado em recebê-lo. Algumas expressões fazem alusão ao fato: "ferro é o ouro da Serra do Norte"; "o machado é a libra esterlina do sertão". 126 O último machado, o de número de ordem 2214, aparece tanto como material etnográfico quanto ressignificação. Em Rondônia, há uma descrição sucinta na figura 63: "Machado feito com uma talhadeira de aço - índios da Serra do Norte" (Figura 15). ${ }^{127} \mathrm{O}$ Tombo acrescenta informações geográficas e outro material: "Machado de ferro encabado - usado por índios habitantes do Alto Guaporé, nas proximidades da antiga cidade de Mato-Grosso - (Cabixis) - maio de X". ${ }^{128}$ A mão, está escrito: 
"O cabo parece ser de um caule [ilegível] (Bauhinia, Dalley) / (Hoehne)" (Figura 15A). A ferramenta em si, de pedra ou de metal, era essencial para o modo de vida Nhambiquara. A ressignificação estava lá, o objeto foi usado para elaborar a narrativa de evolução natural, agindo no seio da cultura Nhambiquara. O instrumental que levaria uma etnia de um estágio a outro na escala civilizacional é medido pelo exemplo e pelo material. As teses evolucionistas eram "provadas" ao indicarem que o machado de pedra já estava em desuso. $\bigcirc$ antropólogo registrou a "humanidade imanente" (leia-se civilizada) que havia nos Nhambiquara pelas pilhérias que faziam do antigo machado de pedra. Viu-se nessa ressignificação uma mão inexperiente copiando uma indústria superior. ${ }^{129}$ As descrições são a observação do engatinhar do homem rumo ao refinamento inerente à capacidade humana. Dentro da lógica evolucionista e colecionista apresentada, o machado de pedra ganha valor de referência não apenas por entrar numa coleção representativa de uma etnia, ${ }^{130}$ mas também pelo desuso do material tradicional. As teorias utilizadas para a análise dos objetos e das etnias também criam uma narração. No catálogo, a articulação entre tipos texłuais descritivos faz os indígenas andarem na direção rumo à civilização ocidental.

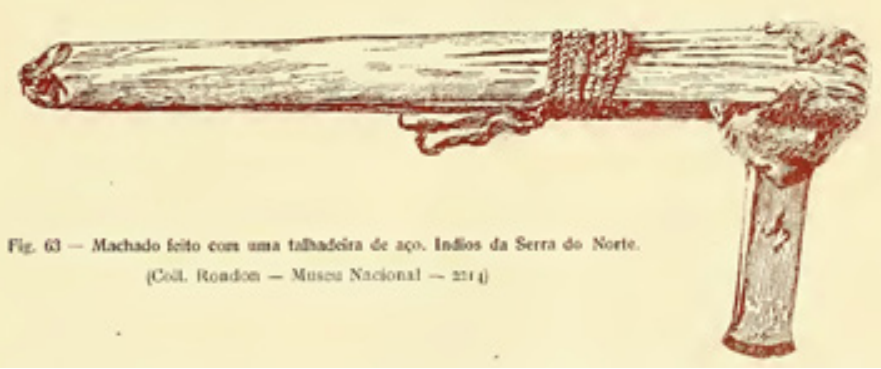

Figura 15 - Machado feito de uma talhadeira de aço. Índios da Serra do Norte. Fonte: Roquette-Pinto (1917, p. 137).

No campo da matéria-prima, encontrei no Tombo o número de ordem 1929 que traz apenas "breu - usado dos índios nhambiquara" coletado por Miranda Ribeiro, em 8 de julho de 1909, na região do Ji-Paraná (Figura 16). ${ }^{131}$ Posteriormente, Roquette-Pinto insere a matéria-prima na chave do discurso da ciência, usando tipos textuais descritivos para relacionar ingredientes, cozimento, conservação e usos. Tanto em "Notas..." quanto em Rondônia, o breu indígena é apresentado como goma de múltipla função, sempre com papel coadjuvante importante. Fixava pontas em flechas, pedras em machados, adereços em cuias e era chamado Duhataarú, que significa cera. ${ }^{132}$ Os dois textos descrevem como massa negra que amolece e se funde em temperatura baixa. $\bigcirc$ sistema de inventário se adensa conforme informações são acrescidas e os itens apresentam suposições sobre os ingredientes:
129. Roquette-Pinto (1917, p. XIV, 188-189)

130. Pomian (1984).

131. Livro de Tombo I.

132. Roquette-Pinto (1917, p. 185). 
133. Id. (1912a, p. 37).

134. Id. (1917, p. 185).

135. Id. (1912a, p. 37).

136. Id. (1917, p. 185).

137. Motta; Oliveira (2006, p. X). "parece que é uma mistura da resina do Oanani - (Syphonia globulifera), e cera", ${ }^{133}$ com cheiro resinoso; "de resina de almêcega - (Protium s.p.), jatahy - (Hymenea courbarill e cera, levando ainda outras substancias desconhecidas". ${ }^{134} \mathrm{~A}$ forma de conservação também apresenta discrepâncias. No texto de 1912, é guardado "envolto nas folhas de uma palmeira". ${ }^{135}$ Em Rondônia está a informação de que é conservado em bolas (13235) ou em formato de pães "envolto em folhas" (1 3213 ). ${ }^{136}$

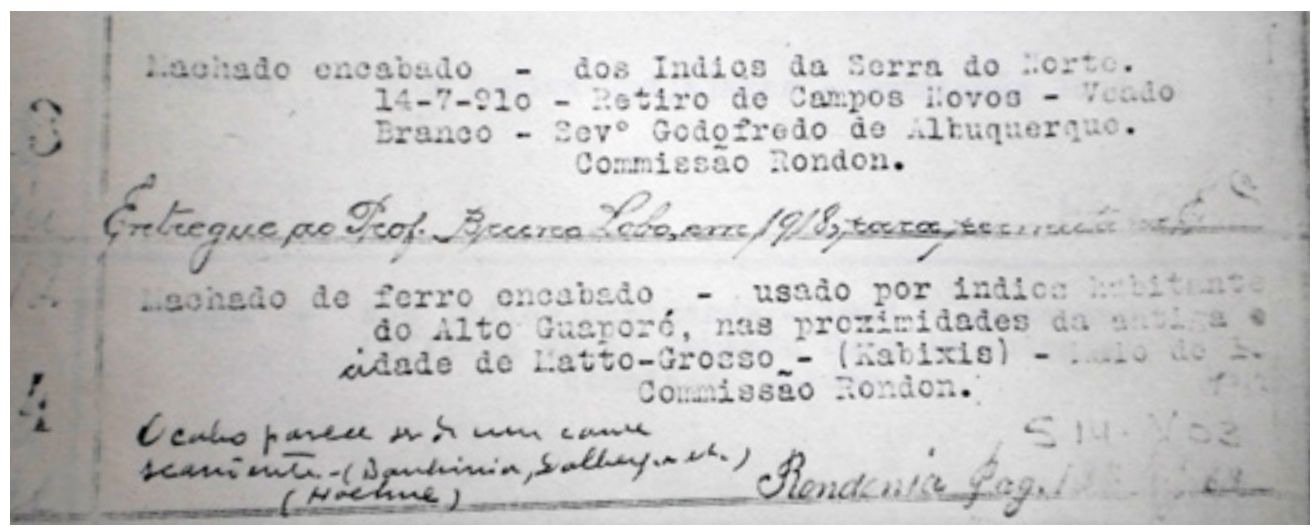

Figura $15 a-$ Na foto por mim tirada por ocasião da pesquisa, aparecem apenas uma parte da dezena (1) e a unidade completa (4) do número de ordem. Como não foi possível refazer a fotografia, visto o material ter se perdido quando do incêndio do Museu Nacional, inferi centena e milhar pela comparação entre as obras. Na descrição do objeto anotado à mão, lê-se "Rondonia pag. [ilegível] 63". No livro de Roquette-Pinto (1917, p. 137), na figura 63, consta o machado feito com talhadeira de aço de número de ordem 2214. Detalhe do Livro de Tombo I, s/p. Acervo do Museu Nacional/UFRJ. Reprodução do autor.

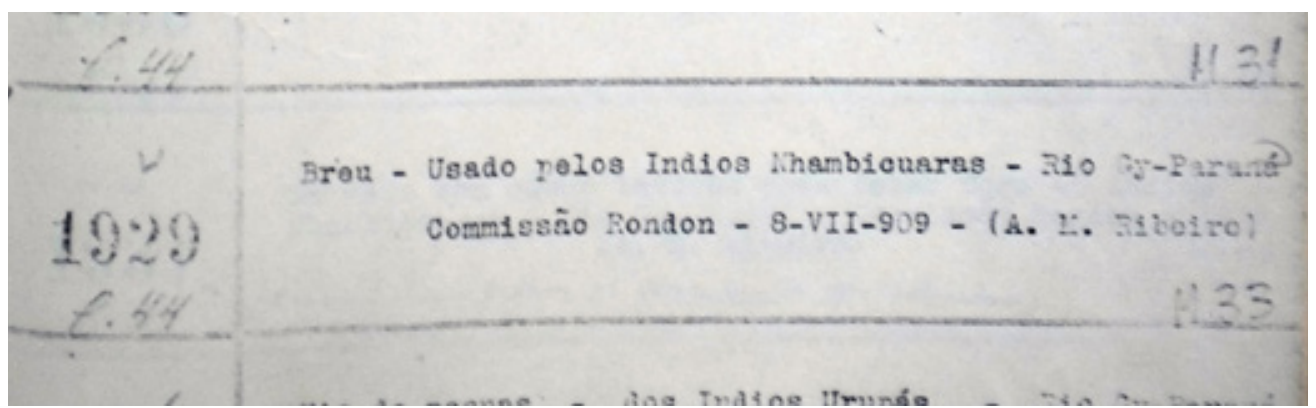

Figura 16 - Detalhe do Livro de Tombo Is/p. Acervo do Museu Nacional/UFRJ. Reprodução do autor.

Os objetos trançados de palha também são descritos no discurso da ciência. Inúmeros estudos mostraram o peso que esta técnica tem nas diversas culturas indígenas. ${ }^{137}$ Os tipos textuais descritivos salientam as matérias-primas, as técnicas de trançado e dimensões, porém, o uso final está na representação. Por motivo de sistematização, trabalho somente com o abano e o cesto. Ambos estão no Tombo apenas como representação, sendo "Abano" (1921) e "Cesta de carregar as costas" 
(1950) pertencentes aos Nhambiquara, do rio Ji-Paraná, e doados por Miranda Ribeiro. Diferenças sutis mostram a mão do catalogador lo abano tem data completa "8-VII-909"; o cesto, apenas o ano) (Figura 17; Figura 17a). ${ }^{138}$

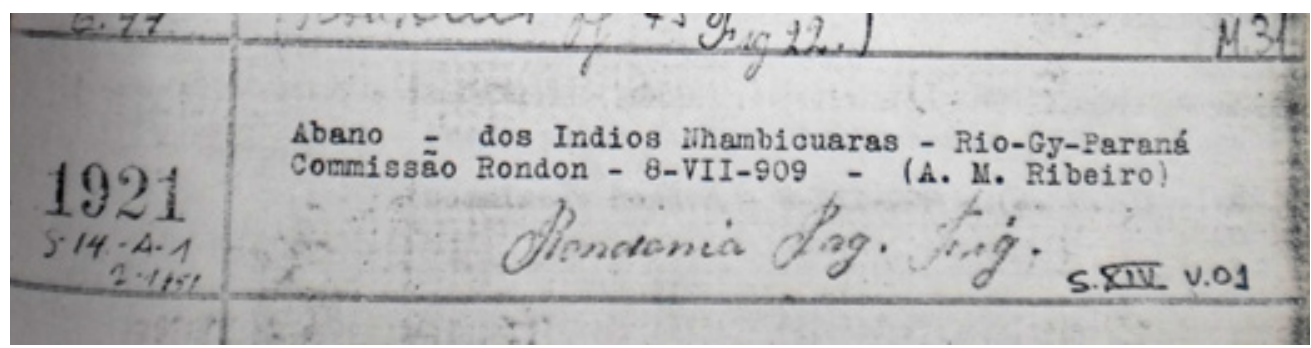

Figura 17 - Detalhe do Livro de Tombo ... s/p. Acervo do Museu Nacional/UFRJ. Reprodução do autor.

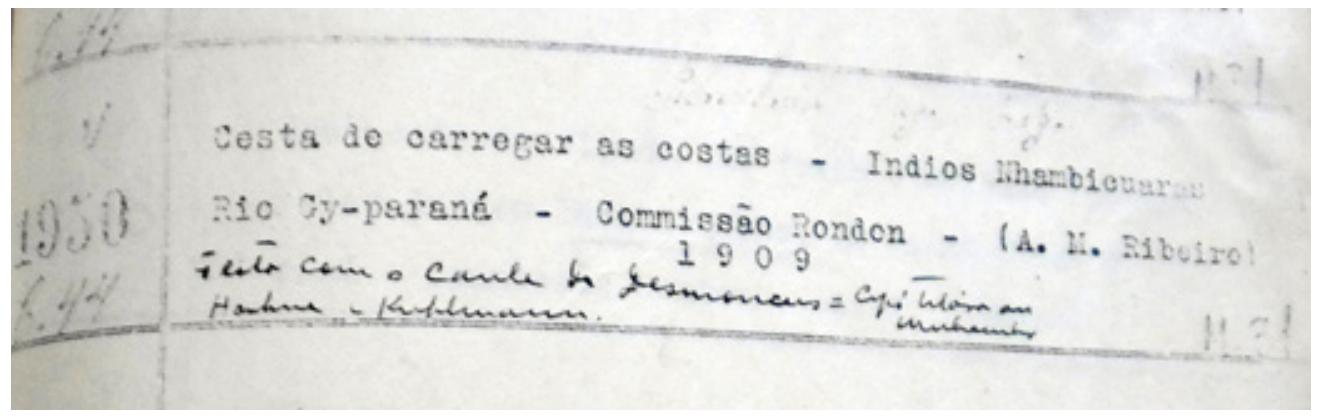

Figura 17a - Detalhe do Livro de Tombo ... s/p. Acervo do Museu Nacional/UFRJ. Reprodução do autor.

Em "Notas...", o abano é apresentado sucintamente: feito de folhas da bacaba trançadas "em grupos de 4, dois a dois". Dados os estudos da cultura material do momento, o cesto é detal hado justamente por seu uso como cargueiro. As tiras de taquara compõem um cesto de " $62 \mathrm{~cm}$ de altura por $33 \mathrm{~cm}$ de diâmetro", com alças presas "no fundo e nas paredes laterais" (Figura 18; Figura 18a). ${ }^{139}$

Como mencionado, a profundidade das análises dos objetos tem reflexo na catalogação estendida. Em Rondônia, Roquette-Pinto sai do registro do objeto e deixa a informação sobre a técnica para outro etnólogo. O autor vê na sistematização dos trançados dos índios brasileiros de Max Schmidt ${ }^{140}$ que o trançado simples e característico do Atiçú, nome étnico do mesmo cesto-cargueiro Nhambiquara, e do mesmo abano é também comum a diversas etnias da região do Xingu. Assim, Schmidt amplia a zona de contato dos índios do Guaporé (Figura 19).

Apenas no último texto a folha de bacaba do abano recebe o nome científico (Oenocarpus sp.). As tiras de taquara do cesto são identificadas como de cipó titara. É importante salientar que na descrição deste item, no Tombo, surge
138. Livro de Tombo I.

139. Roquette-Pinto (1912a, p. 21).

140. Roquette-Pinto (1917, p. 182, 188). 
141. Livro de Tombo I.

142. Roquette-Pinto (1917, p. 185).

Figura 18 - Abano Nhambiquara número de ordem 1921. Fonte: Roquette-Pinto (1912a, p. 37). Acervo da Academia Brasileira de Letras. Reprodução do autor.

um comentário escrito à mão que reafirma o caráter coletivo do catálogo "trata com o caule de Desmoncus = cipó tirana ai. Hoehne e Kuhlmann". ${ }^{141}$ A mesma matéria-prima usada para covo de pescaria (número de ordem 1321 1), "feito de taquara ou do caule do cipó Titára (Desmoncus s.p.)". ${ }^{142}$

\section{OS INDIOS NHAMBIQUÁRAS}

an einem Ende mittelst Pech verstopft und auf dem anderen mit einem Pfropfen aus Baumwollfăden geschlossen. In dieser Röhre befindet sich ein dunkles Pulver, dessen Verwendung bisher nicht bekannt ist.

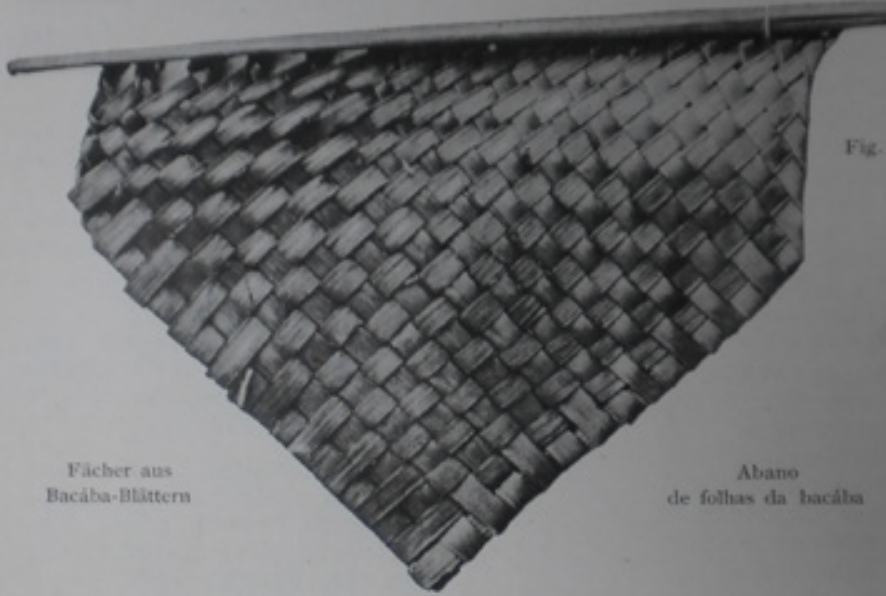

Die Vermutung, dass es sich um eine giftige Substanz handeln könnte ist nicht annehmbar, denn die, auf mein Ersuchen, vom Professor an der medizinischen Fakultät, Alvaro Ozorio de Almeida angestellten physiologischen Studien behufs Feststellung, ob an den Pfeilen dieser Indianer Gift vorhanden sei, ergaben ein negatives Resultat. ")

Es ist sehr wahrscheinlich, dass dieses Pulver, ahnlich dem von vielen brasilianischen Stămmen gebrăuchlichen "Paricà? (Piptadenia peregrina), zum Schnupfen dient.

Âus den Blättern der -Bacábas werden kleine Täschchen, Fig. 5

9) Die Parecis Aincesen betrapten, dass die

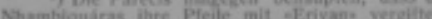

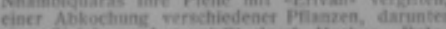
eine Strichnos, festecotem durch Hothine, Bota-

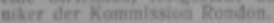

E' massa negra que amolece e funde a temperatura muito baixa, adquirindo intenso brilho, e desprendendo cheiro rezinozo: parece que é uma mistura da rezina do Oanani - (Syphonia globulifera), e 


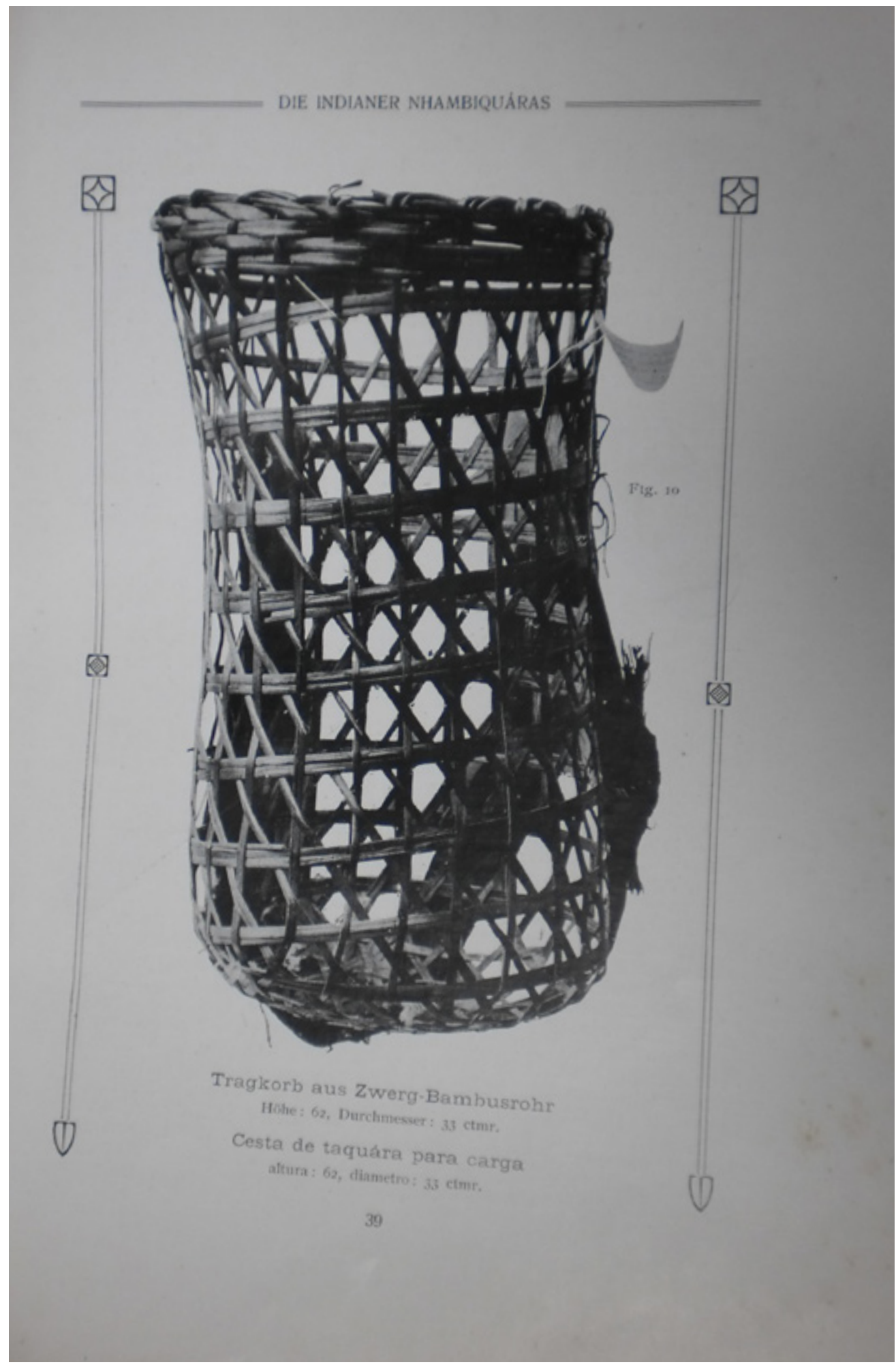

Figura 18a - Cesto de carregar às costas Nhambiquara número de ordem 1950. Fonte: Roquette-Pinto (1912a, p. 39). Acervo da Academia Brasileira de Letras. Reprodução do autor. 
Archivos do Museu Nacional. Vol. XX

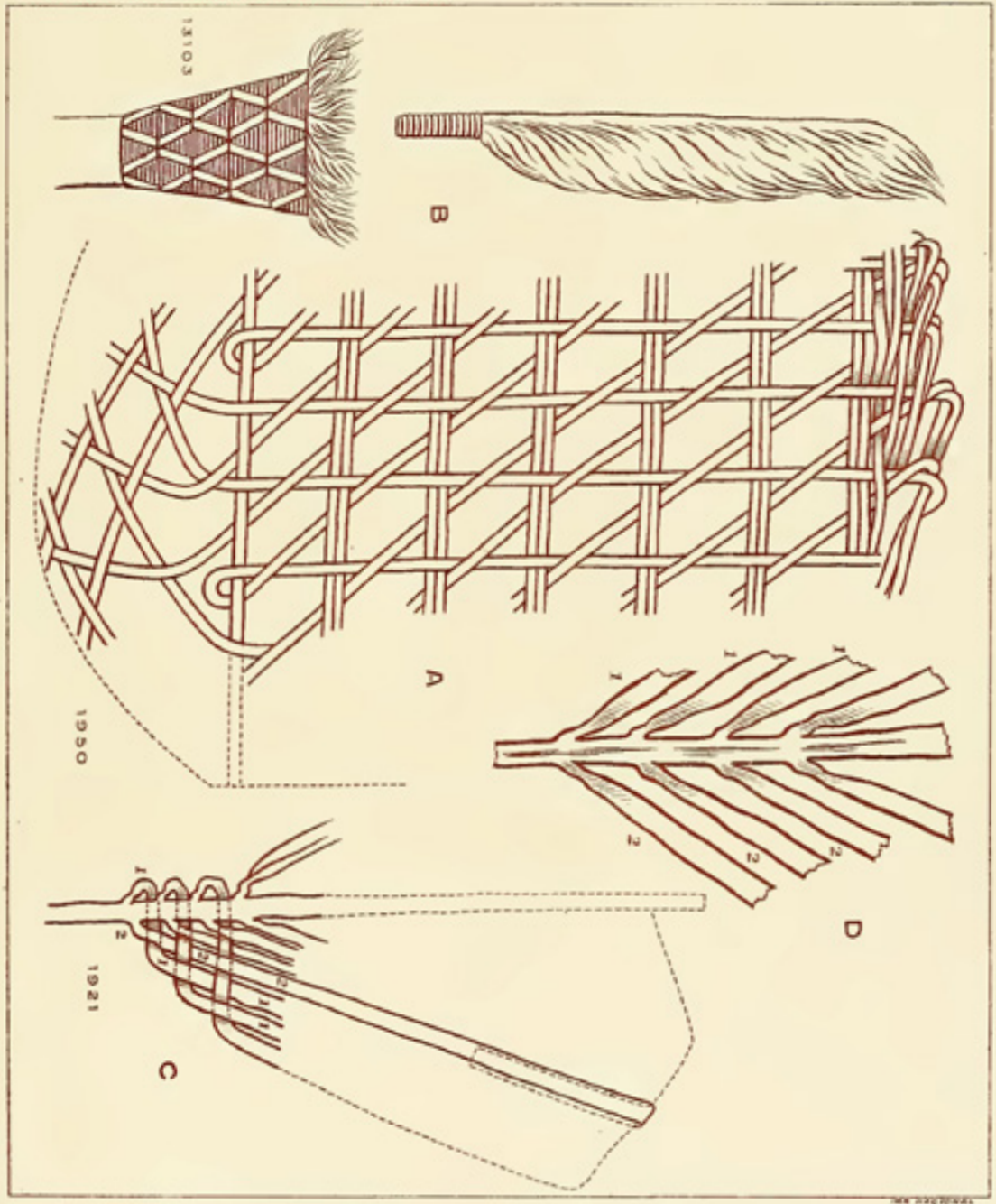

INDIOS DA SERRA DO NORTE

A.- Trancado das cestas feilas com'o caule voluvel de un Desmoncus

B. - Delalhes do pennacho nasal.

C e D-Trancado de um abano, feito com uma palma.

Figura 19 - Sistematização dos trançados Nhambiquara usando o cesto número de ordem 1950 e o abano número de ordem 1921 como exemplos. Fonte: Roquette-Pinto (1917, p. 82). 


\section{CONCLUSÃO}

A ciência auxiliaria a reorganizar o Brasil, e a antropologia seria uma forma de leitura de país. Para cada tipo de texto existe uma chave de leitura. Nesse sentido, muito da antropologia de Roquette-Pinto está no registro de uma catalogação, de uma narrativa compartimentalizada e simultânea da cultura do outro e de si.

Analisar o catálogo como gênero discursivo é procurar uma forma estável de comunicação entre pedaços pequenos e aparentemente estanques de informação. A ideia de inventário detalhado que divide em partes a etnia Nhambiquara perpassa outros textos e o estilo de Roquette-Pinto. Trabalhar com fragmentos de informação que não estão mais disponíveis para consulta é um desafio que deve ser levado em consideração. No entanto, com a ideia de catalogação estendida estudam-se pedaços maiores e menores de informações espalhadas por diversos textos que guardam conexões com o Livro de Tombo.

Não busquei encontrar o redator de cada descrição relativa a cada número de ordem. Com a ideia de empresa coletora pressupus que a classificação foi realizada com base nas informações do coletor, do doador e do classificador. A falta de método na coleta dos objetos se reflete na catalogação, e a escrita antropológica se dá por sequências de descrições com variação de pormenores. $\bigcirc$ cotejo entre os textos, contudo, salienta que há acréscimos de informações em objetos semelhantes, conforme o acúmulo de conhecimento a respeito deles. $\bigcirc$ paralelo entre os textos dá voz também ao objeto que sofre pela ausência de detalhes. Alguns dos problemas desse método catalográfico são o mesmo objeto ter duas classificações diferentes e a discrepância nas descrições de objetos semelhantes. Uma das justificativas dessa etnografia catalográfica reside na ideia de que uma forma de mensuração de uma sociedade/cultura estaria em encontrar e descrever objetos que atestassem a narrativa sobre em qual estágio do desenvolvimento está a habilidade de fabricar e utilizar artefatos.

Jamais se deve ignorar o momento em que essa etnografia foi realizada, afinal o "primitivo" foi alvo de espanto e de espetacularização. A etnografia, personificada em Roquette-Pinto, e a máquina estatal, tendo a Comissão Rondon como seu ente máximo, souberam usar o que encontraram a seu favor. Dentro dos discursos da ciência, onde a antropologia se encontrava, o método de anotação de objetos como costumes não reduz o trabalho do etnógrafo, mas o apresenta inserido em seu tempo, relacionando uma "sensibilidade inata" da produção nativa à ideia evolutiva de cultura. A ideia de fazer uma foto, um instantâneo de um estágio não era apenas criar uma lembrança de algo que se 
iria perder para a civilização ocidental, mas atuava também como modo de tradução do sertão para o litoral. $\bigcirc$ discurso da civilização dos índios era estatal e, por isso, necessitava de uma forma particular de texto. Era necessário aproximar o leitor final da ação realizada por aquele empreendimento. Tal envolvimento se dava pela divisão entre índios e brasileiros e, depois, pela "transformação" de índios em brasileiros. A nação é apresentada como mãe acolhedora que toma conta dos filhos ainda na primeira infância da civilização.

Os tipos textuais usados por cada discurso têm uma operacionalidade na organização do museu. A análise do tipo textual auxilia a compreender a estrutura particular desta catalogação. Nesta lógica, a relação das sentenças anteriores e posteriores parece afrouxada, pois cada objeto pode ser visto em separado. A cultura Nhambiquara foi dividida em pequenos pedaços de informações. As representações/ descriçães são as menores partes de uma cultura e de uma tradução do sertão para o litoral. Para se ter uma visão completa das coleções trabalhadas por Roquette-Pinto é preciso observar a articulação entre os pequenos pedaços de informação. 


\section{REFERÊNCIAS}

FONTES IMPRESSAS

LIVRO DE TOMBO, I, II, III, V e VI. Rio de Janeiro: Museu Nacional. Setor de Etnologia e Etnografia. Rio de Janeiro: [s. n.], [191-?].

LOBATO, Monteiro. Rondônia. O Estado de S. Paulo, São Paulo, 23 abr. 1918. p. 3.

O MUSEU Nacional: uma entrevista com Bruno Lobo. O Imparcial, Rio de Janeiro, 2 abr. 1916. p. 6

ROQUETTE-PINTO, Edgard. Notas sobre os índios Nhambiquaras do Brasil-Central. Revista Brasileira - Brasilianische Rundschau, Hamburgo, p. 25-43, $1912 \mathrm{a}$.

ROQUETTE-PINTO, Edgard. Relatório da $4^{a}$ Secção de Antropologia e Etnografia apresentado ao Sr. Diretor do Museu Nacional, Bruno Lobo. Rio de Janeiro: Arquivo Semear: Museu Nacional, 1912b.

ROQUETTE-PINTO, Edgard. Os índios da Serra do Norte. Jornal do Commercio, Rio de Janeiro, 22 mar. 1913. p. 3-4.

ROQUETTE-PINTO, Edgard. O Brasil e a antropologia. Revista do Brasil, São Paulo, v. 3, n. 12, p. 322-335, 1916.

ROQUETTE-PINTO, Edgard. Rondônia. Archivos do Museu Nacional, Rio de Janeiro, v. 20, 1917. Disponível em: <https://bit.ly/3cy5Zrj>. Acesso em: 23 abr. 2018.

LIVROS, ARTIGOS E TESES

BAKHTIN, Mikhail. Estética da criação verbal. São Paulo: Martins Fontes, 1997.

BARBUY, Heloísa. Documentação museológica e pesquisa em museus. In: GRANATO, Marcus; SANTOS, Claudia Penha; LOUREIRO, Maria Lucia (orgs.). Documentação em museus. Rio de Janeiro: Museu de Astronomia e Ciências Afins, 2008. p. 33-43.

BOAS, Franz. As limitações do método comparativo da antropologia, 1896. In: BOAS, Franz. Antropologia cultural. Rio de Janeiro: Jorge Zahar, 2004. p. 25-40. 
BOTTALLO, Marilúcia. Diretrizes em documentação museológica. In: ASSOCIAÇÃO CULTURAL DE AMIGOS DO MUSEU CASA DE PORTINARI. Documentação e conservação de acervos museológicos: diretrizes. Brodowski: ACAM Portinari, 2010. p. 48-74.

CARVALHO, José Murilo de. A formação das almas: o imaginário da República no Brasil. São Paulo: Companhia das Letras, 1990.

CLIFFORD, James; MARCUS, George (ed.). Writing culture: the poetics and politics of ethnography. Berkeley: University of California Press, 1986.

COSTA-HÜBES, Terezinha. Os gêneros discursivos como instrumentos para o ensino de Língua Portuguesa: perscrutando o método sociológico bakhtiniano como ancoragem para um encaminhamento didático-pedagógico. In: NASCIMENTO, Elvira Lopes do; ROJO, Roxane. Gêneros de texto/discursivo e os desafios da contemporaneidade. São Paulo: Pontes, 2014. p. 13-34.

DUARTE, Regina Horta. Rumo ao Brasil: Roquette-Pinto viajante. In: LIMA, Nísia Trindade; SÁ, Dominichi Miranda de (orgs.). Antropologia brasiliana: ciência e educação na obra de Edgard Roquette-Pinto. Belo Horizonte: Editora UFMG; Rio de Janeiro: Editora Fiocruz, 2008. p. 271-294.

EWBANK, Cecília Oliveira; LIMA FILHO, Manuel Ferreira. Por detrás de uma coleção do Museu Nacional do Rio de Janeiro: vozes, silêncios e desafios. MIDAS, Évora, v. 8, 2017. Disponível em: <https://bit.ly/3cx7i9R>. Acesso em: 17 out. 2017.

GRUPIONI, Luiz. Os museus etnográficos, os povos indígenas e a antropologia: reflexões sobre a trajetória de um campo de relações. Revista do Museu de Arqueologia e Etnologia, São Paulo, v. 7, p. 21-33, 2008.

KUPER, Adam. Culture: the anthropologists' account. Cambridge: Harvard University Press, 1999.

LACERDA, João Batista de. O Congresso universal das raças reunido em Londres (1911): apreciação e comentários. Rio de Janeiro: Papelaria Macedo, 1911.

LIMA, Antônio Carlos de Souza. Um grande cerco de paz: poder tutelar e indianidade no Brasil. Petrópolis: Vozes, 1995.

LIMA, Nísia Trindade; SÁ, Dominichi Miranda de. Roquette-Pinto e sua geração na república das letras e da ciência. In: LIMA, Nísia Trindade; SÁ, Dominichi Miranda de (orgs.). Antropologia brasiliana: ciência e educação na obra de Edgard Roquette-Pinto. Belo Horizonte: Editora UFMG; Rio de Janeiro: Editora Fiocruz, 2008. p. 57-84.

LIMA, Nísia Trindade; SANTOS, Ricardo Ventura; COIMBRA JR., Carlos. Rondonia de Edgard Roquette-Pinto: antropologia e projeto nacional. In: LIMA, Nísia Trindade; SÁ, Dominichi Miranda de (orgs.). Antropologia brasiliana: ciência e educação na obra de Edgard RoquettePinto. Belo Horizonte: Editora UFMG; Rio de Janeiro: Editora Fiocruz, 2008. p. 99-122. 
MACHADO, Maria Fátima. Índios de Rondon: Rondon e as linhas telegráficas na visão dos sobreviventes Wáimare e Kaxíniti, grupos Paresí. 1994. Tese (Doutorado em Antropologia Social) - Universidade Federal do Rio de Janeiro, Rio de Janeiro, 1994.

MARCUSCHI, Luiz Antônio. Gêneros textuais: definição e funcionalidade. In: DIONÍSIO, Ângela; MACHADO, Anna Raquel; BEZERRA, Maria Auxiliadora (orgs.). Gêneros textuais $e$ ensino. Rio de Janeiro: Lucerna, 2002. p. 19-39. Disponível em: <https://bit.ly/2OsSxge>. Acesso em: 23 abr. 2017.

MILLER, Daniel. Teorias das coisas. In: MILLER, Daniel. Trecos, troços e coisas: estudos antropológicos sobre a cultura material. Rio de Janeiro: Zahar, 2013. p. 66-118.

MOTTA, Dilza Fonseca da; OLIVEIRA, Leandra de. Tesauro de cultura material dos índios no Brasil. Rio de Janeiro: Museu do Índio, 2006.

MURARI, Luciana. Brasil: ficção geográfica, ciência e nacionalidade no país d'Os sertões. Belo Horizonte: Fapemig; São Paulo: Annablume, 2007.

MUSSIO, Simone. Um olhar alteritário em Bakhtin: o estudo do enunciado como forma de diálogo. SOLETRAS, Rio de Janeiro, n. 30, p. 176-190, 2015.

NASCIMENTO, Fátima. A formação da Coleção de Indústria Humana do Museu Nacional, século XIX. 2009. Tese (Doutorado em Antropologia Social) - Universidade Federal do Rio de Janeiro. Rio de Janeiro, 2009.

ORLANDI, Eni Pulcinelli. Análise de discurso: princípios e procedimentos. Campinas: Pontes, 2000.

ORLANDI, Eni Pulcinelli. Vão surgindo sentidos. In: ORLANDI, Eni Pulcinelli (org.). Discurso fundador: a formação do país e a construção da identidade nacional. Campinas: Pontes, 2001. p. 11-25.

POMIAN, Krysztof. Colecção. In: ENCICLOPÉDIA Einaudi, volume 1: memória-história. Lisboa: Imprensa Nacional: Casa da Moeda, 1984. p. 51-86.

RIBEIRO, Alípio de Miranda. A Comissão Rondon e o Museu Nacional (conferências realizadas pelo professor Alípio de Miranda Ribeiro, no Museu Nacional do Rio de Janeiro, em 1916). 2. ed. Rio de Janeiro: Ministério da Agricultura: Comissão Nacional de Proteção aos Índios, 1945.

SANTOS, Ricardo Ventura. Os debates sobre mestiçagem no Brasil no início do século XX: Os sertões e a medicina-antropologia do Museu Nacional. In: LIMA, Nísia Trindade; SÁ, Dominichi Miranda de (orgs.). Antropologia brasiliana: ciência e educação na obra de Edgard RoquettePinto. Belo Horizonte: Editora UFMG; Rio de Janeiro: Editora Fiocruz, 2008. p. 123-146. 
SANTOS, Rita de Cássia Melo. No "Coração do Brasil": Roquette Pinto e a Expedição à Serra do Norte (1912). 2011. Dissertação (Mestrado em Antropologia Social) - Universidade Federal do Rio de Janeiro, Rio de Janeiro, 2011.

SCHWARCZ, Lilia Moritz. O espetáculo das raças: cientistas, instituições e questão racial no Brasil 1870-1931. São Paulo: Companhia das Letras, 1993.

SILVA, Jane Quintiliano Guimarães. Gênero discursivo e tipo textual. Scripta, Belo Horizonte, v. 1, n. 1, p. 87-106, 1999.

STOCKING JR., George. Franz Boas and the culture concept in historical perspective. In: STOCKING JR., George. Race, culture and evolution. Chicago: The University of Chicago Press, 1982.

STOCKING JR., George (ed.). Objects and others: essays on museums and material culture. Madison: The University of Wisconsin Press, 1985.

TACCA, Fernando de. Rituaes e festas Bororo: a construção da imagem do índio como "selvagem" na Comissão Rondon. Revista de Antropologia, São Paulo, v. 45, n. 1, p. 187-219, 2002.

VELLARD, Jean. Preparação do curare pelos Ñambikwaras. Revista do Arquivo Municipal. São Paulo: Arquivo Municipal de São Paulo, n. LIX, p. 5-16, 1939.

VELOSO JR., Crenivaldo. Índice de objetos, índice de histórias: o catálogo geral das coleções de antropologia e etnografia do Museu Nacional. Ventilando Acervos, Florianópolis, v. esp., n. 1, p. 71-89, 2019.

VENTURA, Renato. Estilo tropical: história, cultura e polêmicas literárias no Brasil. São Paulo: Companhia das Letras, 1991.

VIVEIROS, Esther. Rondon conta sua vida. Rio de Janeiro: Livraria São José, 1958.

SITES

MINICURSO “A economia libidinal do fascismo" - Parte 1. Brasília, DF: UnB, 2019. 1 vídeo (79 min). Publicado pelo canal Grupo de pesquisa Afetos e Política. Disponível em: <https:// bit.ly/3eAHbkV>. Acesso em: 10 jan. 2020.

Artigo apresentado em: 12/08/2020. Aprovado em:15/02/2021. (cc) BY

All the contents of this journal, except where otherwise noted, is licensed under a Creative Commons Attribution Licens 